\title{
BANK CONTROL AND THE NUMBER OF BANK RELATIONS OF JAPANESE FIRMS
}

\author{
KAZUO OGAWA \\ ELMER STERKEN \\ ICHIRO TOKUTSU
}

CESIFO WORKING PAPER NO. 1589

CATEgory 6: MONETARy Policy and InTERnational FinanCE NOVEMBER 2005

\footnotetext{
An electronic version of the paper may be downloaded

- from the SSRN website:

www.SSRN.com

- from the CESifo website:

www.CESifo-group.de
} 


\title{
BANK CONTROL AND THE NUMBER OF BANK RELATIONS OF JAPANESE FIRMS
}

\begin{abstract}
We explore the determinants of the number of long-term bank relations of listed Japanese firms using a unique data set covering the period 1982-1999. Japanese listed firms have about seven long-term bank loan relations on average, but show a large variation around the average. We analyze the determinants of the choice for the number of bank relations. We use data on loan and equity ownership to address the impact of the Japan-specific bank-firm relations and bank control on the number of loans decision. Having a relation with a topequity holding bank reduces the number of bank relations, while debt-rich and cash-poor firms have more bank relations.
\end{abstract}

JEL Code: G21, G32.

Keywords: firm-bank relations, single versus multiple borrowing, bank control, discrete choice models.

Kazuo Ogawa
Institute of Social and Economic Research
Osaka University
6-1 Mihogaoka, Ibaraki
Osaka 567-0047
Japan
ogawa@iser.osaka-u.ac.jp

Ichiro Tokutsu

Institute of EBA Studies

Konan University

8-9-1 Okamoto Higashi-nada

KOBE 658-8501

Japan

tokutsu@center.konan-u.ac.jp

This research is supported by Grant-in-Aid for Scientific research (\#16330038) from the Japanese Ministry of Education, Culture, Sports, Science and Technology in 2004. We are grateful to the Zengin Foundation for Studies on Economics and Finance for financial support, and thank Elena Carletti, Hans Degryse, Maarten Gelderman, Heinz Hermann, Robert Lensink, Steven Ongena, and participants at the Econometric Society Meetings in Venice and seminars at the University of Amsterdam, De Nederlandsche Bank, and the Bundesbank for valuable comments. 


\section{$1 \quad$ Introduction}

We analyze the choice of the number of long-term banking relations of Japanese listed firms in the period 1982-1999. Firm-bank relations are in the core of Japanese economic development in the post-war period and it is widely believed that long-term loans were essential to enhance the rapid Japanese economic growth in the 1960s and 1970s. As known, in post-war Japan long-term bank loans were the number one source of external funds for almost all firms (see Fukuda, 2001). Except for a few cash-rich firms internal financing was limited in general. As Ito (1992) shows, internal financing in the 1960s and 1970s was only about $20 \%$ of the total corporate financial needs (as compared to $50 \%$ for the U.S.). The dominant role of long-term loans in external finance is reflected in the fact that until the mid-1980s bond financing was strictly regulated (even after 1985 only very large firms were able to issue bonds).

It should be noted that the large banks were key players in the Japanese industrial group structure called keiretsu, wherein lending activity, combined with equity ownership, is relatively important (see e.g. Flath, 1993). In the keiretsu structure firms have a strong and long-lasting relation with the bank in the group, called the main bank. It is true that the main bank plays a dominant role in providing loans to the affiliated firms, but the firms nonetheless borrow from banks outside the group. We investigate why firms depend on other banks besides their main bank and what determines the optimal number of creditors in the presence of main banks.

It is often argued that the bank-firm relationship changed in the course of bubbleand post-bubble period. There are several factors that explain this change. First, financial deregulation allowed firms to issue public debt, which made firms less reliant on bank loans. Secondly, banks are burdened with heavy non-performing loans after the bubble burst, which hindered the intermediary role of banks. So it is still an interesting question how the change of bank-firm relationship affected the optimal number of creditors. The rather unique feature of our data enables us to answer this question empirically. Our data set contains the time-series information for long-term loans for the years 1982-1999. This period covers the bubble and the post-bubble years. How does the bad loan problem affect individual firm decisions to contract banks? We illustrate this in Figure 1 that gives the percentage of single-bank relations of 14055 firm-year observations for the years 
1982-1999. The percentage of single-bank to all relations is at most $13 \%$ and Japanese firms do have multiple banking contacts on average. Figure 1 also suggests that during the bubble period firms tended to rely on a single relation, while in the period of long stagnation after the bubble burst the average percentage of multiple contracts increased. This finding stresses the need for further analysis.

Our study based on the unique data set has advantage over the past studies. Contrary to earlier 'static survey' studies on the optimal number of bank relationships

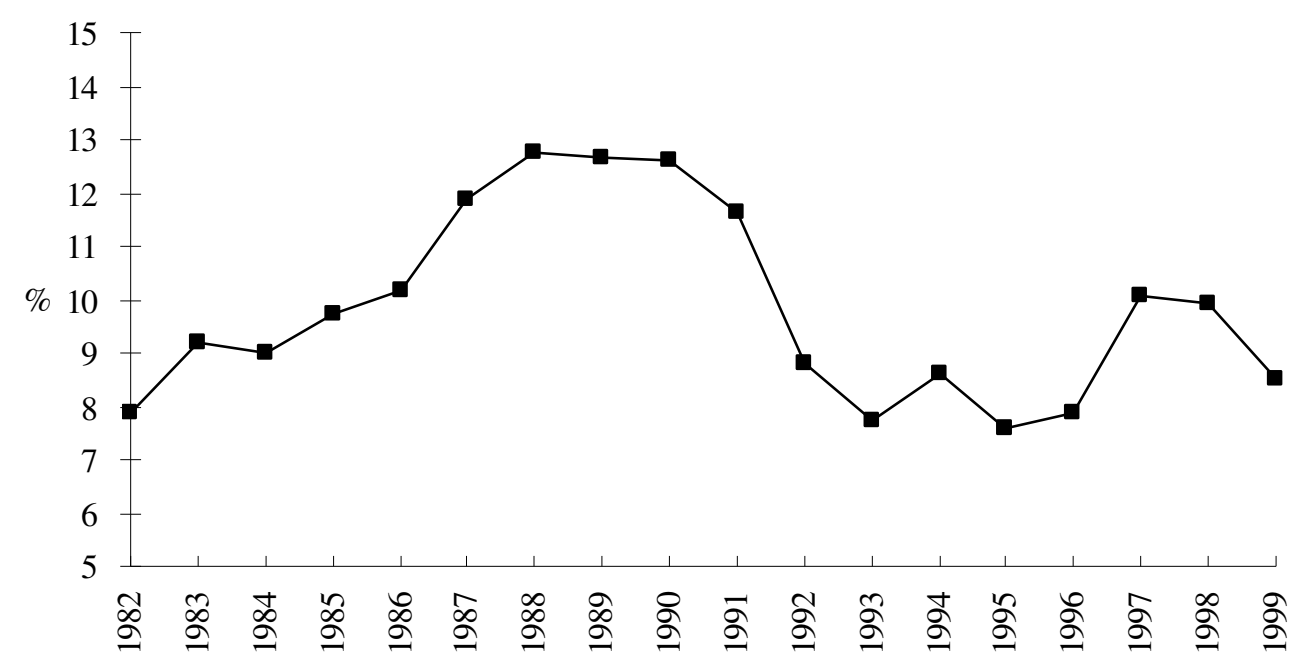

Figure 1. Percentage of firms with a single long-term loan relation

(see e.g. Detragiache et al., 2000, Degryse and Ongena, 2001, and Houston and James, 2001) we exploit, like Farinha and Santos (2004) and Foglia et al. (1998), the time variation in our extensive data set. Farinha and Santos, though, focus on the timing of switching from one to multiple bank relations for especially young firms and Foglia et al. on the effects of the borrowing structure on the thoroughness of the banking system's overall monitoring of individual borrower firms. The scope of our paper is broader as we have a general interest in multiple relations of large listed Japanese firms, for which control of ownership matters. We include information with respect to the Japanese corporate (bank) control mechanism using variables that define top loan and equity ownership on the firm level. This feature is especially relevant to the keiretsu structures. 
We proceed as follows. First we give a review of the theoretical and empirical literature on the determination of the optimal number of bank relations. The theoretical background of our paper is a key problem in financial economics: what is the optimal number of creditors? These creditors can be holders of either public or private claims. We analyze the private component, namely the number of bank contracts per firm. This literature is largely based on the theory of corporate finance. In this literature one is interested in the game between the provider of capital and the firm regarding the control rights that belong to the assets. This game can cover the choice between equity and debt, the rights of equity holders (Shleifer and Vishny, 1997), or the composition of external financing (Bolton and Scharfstein, 1996). We review the relevant literature and select the variables that might influence the choice of the number of bank contacts. We pay special attention to the literature that relates the theory of the optimal number of bank contacts and the role of main banks. Next we describe the data we use. The data are provided by the Development Bank of Japan and form a rather rich set of detailed balance sheet and profit-loss account data as well as indicators of ownership of both (long-term) loans and equity. We give an extensive descriptive overview of the variables of interest in Section 3. In Section 4 we present an econometric analysis of the decision to borrow from different banks. Since our main dependent variable, the number of bank relations, is a discrete variable we estimate several discrete choice models. Moreover, we present results for the explanation of the loan concentration ratio (measured by the Herfindahl index). We find that size, profitability, solvability, liquidity, and alternative financing forms determine the number of banking contacts. We find especially support for the liquidity insurance argument to have multiple relations. Finally we show that firms having a so-called main bank relation tend to have a preference for multiple loan contacts. In the last section we summarize and conclude.

\section{Theory and empirical evidence on the optimal number of banking relations}

One of the most interesting fields in finance is the topic of coordination problems between suppliers of capital. These problems hold with respect to owners of equity (which lead to the governance problems like described by Shleifer and Vishny, 1997) and 
the suppliers of debt. Such coordination failures can be harmful and lead to takeover failures (like the depositors in the Diamond-Dybvig model) or renegotiation problems (see Bolton and Scharfstein, 1996). For debt it is natural to distinguish between public debt (bonds) and credit. By definition, by selecting private credit the firm opts for a higher concentration of claims (see Bris and Welch, 2005).

Across the globe it is widely observed that firms deal with more than one bank. Ongena and Smith (2000b) present an overview of studies of various countries and find a range of the average number of banking relationships between 1.6 for small US firms in 1987 to even 33.2 for Italian firms with a credit line over 500 billion Lira in 1993. Ongena and Smith (2000a) carry out an international comparative overview of 20 countries and observe that larger firms (as measured by sales) hold more bank relations, but firms that do more foreign business typically have less domestic banking contacts. Country variation in financial systems is relevant in explaining the country variation in mean banking relations. Firms that reside in countries with poor creditor rights and inefficient judicial systems typically have more banking relationships. If the banking sector is not concentrated but stable and bond markets are effective, the number of relationships per firm is higher. Volpin (2000) puts forward that countries with low shareholder protection allow for higher private benefits of control and through that allow for more banking relations.

Horiuchi $(1993$, 1994) presents the most detailed descriptive analysis of the borrowing decisions by Japanese firms up to now. Horiuchi (1993) reports for 1990 an average number of bank relations for 126 firms with less than 300 employees of 3.4 and for 309 firms with more than 300 employees an average number of relations of 7.7. Horiuchi (1994) reports for 1992 an average (and median) number of 3 relations for 364 firms (including small firms with less than 10 employees). Note that the sample period is up the 1980s and they are not silent on the number of banking relations in the 1990s. 


\subsection{The theory of multiple bank relationships}

The most intuitive explanation of the existence of a single bank relation is based on cost minimization. To deal with more than one bank is costly. First, transaction costs increase, because both screening and monitoring costs are duplicated. It is more expensive to market debt claims to multiple creditors (see Bris and Welch, 2005). These arguments are at the core of the Diamond (1984) delegated monitoring model. The Diamond model predicts a firm to deal with a single bank that pools the costs of asymmetric information. A single bank moreover avoids free-riding problems by private investors. So in all activities prior and during the loan contract it would be cheaper to deal with a single bank. But also in ex post cases, like in the case of bankruptcy, multiple relations will increase the costs of e.g. handling debt renegotiation (see Boot and Thakor, 1994, and Bolton and Scharfstein, 1996).

The second determinant of the number of banking relationships is the degree of competition in the banking market. If competition is low (a few institutions dominate the market) it is likely that the number of banking relationships drops. The incumbent bank will be able to extract rents (see Broecker, 1990). On the other hand if competition is fierce and a large number of competing banks fight for new loans, firms will try to benefit and increase the number of bank contacts.

Third, and related to the second item, is the hold-up problem. If a relationship bank is not affected by heavy competition, it might consider using the acquired private corporate information to extract rents, thus distorting entrepreneurial incentives and causing inefficient investment choices (see Sharpe, 1990, and Rajan, 1992). Carletti (2004) presents a theoretical monitoring model to explain this. Multiple banking entails duplication of effort and sharing of benefit, which lead to a reduction in the overall monitoring intensity but not necessarily to higher loan rates, due to the presence of diseconomies of scale in monitoring. Another form of the hold-up problem might also exist. In a competitive banking environment a high-quality firm that tries to switch from its previous to a new loan provider gets pooled with low-quality firms and might be 
forced to pay too high an interest rate. This prevents a high-quality firm from increasing the number of banking relationships. How do these issues affect the desired quantity of banking relations of a firm? A firm that faces a monopolistic banking industry might want to increase the number of contacts and try to force banks to compete in making offers (see Von Thadden, 1994). This is true for symmetrically informed banks. If we have the opposite case, an inside bank that competes with outside banks, this might change. If outside banks start to compete, the inside bank can use its knowledge on the quality of firms to select the good firms and leaving the lemons as leftovers to the outside banks. This might lead to too high interest rates and a reduction of the number of credit lines. So it is relevant to determine the nature of the existing firm-bank relationships. Petersen and Rajan (1995) give a final argument to the competition issue. They argue that borrowing from banks with great market power facilitates intertemporal sharing of the rent surplus and through that stimulates a single banking relation. Competition in credit markets hinders this process. It might even be so that competition forces rents to the point where it is no longer in the interest of any bank to lend to the firm. Petersen and Rajan (1995) argue that the intertemporal rent sharing is especially crucial to smaller and younger firms.

A fourth class of arguments against the case of single banking relates to using multiple contacts as insurance against liquidity or liquidation risk. The worst case for the firm is that a profitable project has to be liquidated prematurely. Suppose that the loan includes a refinancing stage. If the relation bank cannot rollover their initial loan the firm in liquidity need has to apply for loans from non-relation banks (arm's-length financiers). These banks probably think that the applying firms have 'lemon' projects (see also Detragiache et al., 2000).

A fifth class of arguments is formed by the ability among lenders to coordinate activities in an environment with so-called soft-budget constraints. In a largely decentralized economy banks cannot commit to finance unprofitable long-term projects because dispersed banks with limited capital will find it costly to coordinate actions (Dewatripont and Maskin, 1995). Bolton and Scharfstein (1996) and Bris and Welch (2005) give a 
similar argument. In the Bolton-Scharfstein-model the manager has an incentive to strategically default the project (e.g. by diverting cash to herself). Coordinating with multiple lenders disciplines the manager. On the other hand it might be the case that fewer creditors have more incentives to check managers. Such creditors have an incentive to invest more in monitoring activity (see Bris and Welch, 2005). Writing debt contracts with multiple lenders is costly though (see the first class of arguments). In any case, a decrease of default risk will increase the number of lenders. The same holds to the degree of synergy between the assets of the firm (the degree to which the assets are worth more together than apart) or the liquidation value.

Finally, the type of business activity might affect the number of creditors. Take the example of a highly innovative, high quality firm that invests to a large extent in R\&D. If this firm believes that it will be successful, it will not be willing to give all the information to multiple financiers (see Yosha, 1995). Low-quality firms on the other hand might want to contact multiple banks. Von Rheinbaben and Ruckes (1998) analyze a model that includes the competition on the output market for firms. The main point is again that leakage of information is detrimental to a firm's success on the output market. The firm can avoid this in two ways. First, it decides on the amount of information given to creditors, and second, it can change the number of contacts. If a firm gives more information to a bank and its quality is high, it can get a lower interest rate. More creditors again intensify competition. Highly rated firms optimally try to deal with many banks and will disclose as little information as they can. Bhattacharya and Chiesa (1995) stress the point that it might be optimal for a bank to inform competitors of the innovating firm with respect to the new technology in order to avoid financial distress. Bolton and Scharfstein (1996) also predict that firms in non-cyclical industries will chose a lower number of lenders.

\subsection{Optimal number of creditors and main bank relations}

The main bank of a firm is frequently defined as the bank with the largest share of loans. However, main bank relations are not simply confined to lending relationships, but cover a wider spectrum of aspects. Aoki et al. (1994) stress five aspects of main bank 
relations: lending relationship, client issuances of public debt, equity cross-shareholding, business settlement accounts, and provision of information services and managerial resources. Intertwined with each other, these relations determine the optimal number of creditors for the firms affiliated with their main bank. However, there are very few studies directly dealing with the determination of the optimal number of creditors in the context of a main bank system.

To consider this issue, it is important to understand why main bank financing is so prevalent. Hoshi and Kashyap (2001) discuss benefits and costs of main bank financing. A main bank holds a large share of loans of affiliated firms, which gives a strong incentive to collect information about firms' prospects and to monitor the firms. It helps to mitigate problems with asymmetric information that lead to adverse selection and moral hazard. The studies of Kaplan and Minton (1994), Sheard (1994a), Kang and Shivdasani (1995, 1997), Miyajima (1998), and Morck and Nakamura (1999) provide the evidence that main banks closely monitor their client firms and dispatch directors to them in the event of financial trouble. Close monitoring by a main bank enables other banks to reduce the resources spent on gathering information and monitoring, as is suggested by Diamond's delegated monitoring model (see Diamond, 1984). Other banks let the main bank monitor the firm on behalf of them. Sheard (1994b) discusses the efficiencies of main bank lending from the standpoint of avoidance of monitoring duplication. Having the main line of credit from a main bank, it might also be easier for the firm to attract more loans from other banks. Close monitoring also helps to identify the types of distress their clients face and thus reduce the cost of distress (Hoshi et al., 1990, and Sheard, 1994c). Furthermore, shareholding by a main bank leads to mitigation of conflict between equity holders and debt holders. ${ }^{1}$ Taken together, affiliated firms might raise funds easily from other banks since other banks do not have to bear the expenses associated with lending. Thus the optimal number of creditors will be larger for firms affiliated with a main bank than independent firms.

\footnotetext{
${ }^{1}$ It should be noted that group main banks are not always acting in the interest of the firms, given that these firms are charged higher interest rates (see Weinstein and Yafeh, 1998).
} 
However, it should be noted that concentration of information about affiliated firms at a main bank is a double-edged sword. Sheard (1989) argues that a Japanese firm might also be afraid of monopoly exploitation by the bank, or banks themselves want to share risk, or regulation might block larger loan supply by a single bank. So, there can be different arguments, even in the group structure cases, why firms borrow from multiple banks. Prowse (1990) argues that debt-rich firms tend to invest in projects that benefit shareholders. A way to circumvent this agency problem is to align the debt and equity stakes in the firm. From a slightly different angle, we might argue that too much dependence on main bank is harmful to its affiliated firms. In the 1990s banks were burdened with massive suffer non-performing loans, which hindered the intermediary role of banks severely. In this situation excessive reliance on a main bank makes it difficult for its affiliated firms to switch loans from one bank to the other since other banks have not accumulated information on those firms.

\subsection{Empirical evidence}

The empirical literature on explaining the number of banking contacts is typically more concentrated than its theoretical equivalent. Here we discuss a few studies and summarize these, if relevant, in Table 1. Ongena and Smith (2000a, 2000b) give an overview of international studies on single versus multiple banking relations. Early studies were mainly concerned with the consequences of relationship lending relations on the costs and availability of credit to firms. Borrowing from fewer banks is found to lead to a larger availability of credit to smaller firms (Petersen and Rajan, 1994, and Cole, 1998), but more availability to listed firms (Houston and James, 1996) and lower costs (Petersen and Rajan, 1994, and D'Auria, et al. 1999). In an early study Foglia et al. (1998), analyzing about 1900 Italian small and medium-sized firms, find that having more bank relations, monitoring of the firm becomes weaker, and financial fragility increases. This study though does not endogenize the number of banking contacts.

Detragiache et al. (2000) present a theoretical model of relationship lending. They show that multiple bank contacts can reduce the probability of an early liquidation of a firm's project. Detragiache et al. (2000) test their theory using a set of 1,849 small and medium- 
sized Italian firms. They find that the number of relations tends to increase with firm size, leverage, and age of the firm. Firms with a lower profitability tend to have more single relations. Bank fragility has a positive impact on the number of bank relations. If the size of the bank increases the number of relations drops. Ongena and Smith (2001) use a 1996 survey among large European firms to establish cross-country differences in the number of bank relations per firm. They use cash management relations as the unit of observation. They use both country- and firm-level data as determinants of the number of banking contacts. It appears that on the firm level larger home sales decreases the number of banking relations, while larger worldwide sales increases the number of banking contacts. These characteristics refer to the relevance of the type of business the firms are in. Houston and James (2001) randomly select 250 US firms from the CRSP dataset. This is a set of large listed firms that have multiple financing possibilities. They find that a high market-to-book ratio and a high leverage decrease the probability of a single bank relation. Firm size is negatively related to single bank dependence. A high coverage ration indicates a larger probability of a single bank relation. More uncertainty in asset returns predicts a higher probability of a single relation. Degryse and Ongena (2001) analyze a set of almost all listed Norwegian firms in the years 1979-1995. They find that less profitable, younger, more-leveraged, and larger firms establish more banking relations. Also relevant to our study, firms having a large main bank relation tend to have multiple lending contacts. Finally, Farinha and Santos (2004) analyze a sample of 1,577 young Portuguese firms. They are interested in the duration of a single lending relation and estimate a survival model. It appears that firms with poor performance and firms with large growth options switch with a higher probability to multiple lending relations.

Given the theoretical arguments in section 2.1 we classify the determinants of singlebanking relationships along the six theoretical classes presented above in Table 1 (so a + in Table 1 is a positive stimulus for single banking). The classification of variables is in some cases arbitrary, but illustrative for our purposes. There is at least mixed evidence for the first class: cost minimization. The age of the firm is only found to be important in the Portuguese case. The evidence on firm size is mixed. With respect to the industrial organization of the banking market (which we combine with the hold-up problem) there 
seems to be a clue for the fact that a more concentrated banking market predicts single relations. Not all studies present results with a straightforward interpretation though. By far the most important category is the class of liquidity/liquidation risk. The coordination problems seem to be less relevant. With respect to the business activity there is not much hard statistical evidence to be favored.

\section{Table 1 - Overview of empirical results on single-bank relationships}

\section{Class of explanation/variable}

\section{Cost minimalization}

Firm size

Firm age

Share of defaulted loans recovered

Nonperforming loans

2/3 Competition on the banking market and Hold-up problems

Average size of lending banks

Group membership

\section{Liquidity risk}

Liquidity shocks

Profitability

Coverage ratio

5 Coordination problems/Soft-budget

Firm leverage

Share of first owner

6 Type of business activity

Patents

R\&D

Product innovation

Process innovation

Industry comovement

Variability of asset returns

Home sales

Worldwide sales
DGG $\quad$ FS $\quad$ OS $\quad$ DO $\quad$ HJ

$\begin{array}{llll}+ & - & - & - \\ 0 & + & - & 0 \\ + & & & \\ 0 & & & \end{array}$

DGG = Detriagiache, Garella, Guiso (2000)

FS = Farinha, Santos (2000)

OS = Ongena, Smith (2000a)

DO $=$ Degryse, Ongena (2001)

$\mathrm{HJ}=$ Houston, James (2001)

$+=$ significant determinant in explaining a choice for a single banking relation;

$0=$ insignificant determinant;

- = significant determinant in explaining a choice for multiple banking 


\section{Description of the data}

The primary sources of data are the Financial Statement Data (FSD) and Sources of Loans Data (SLD) of individual firms. Both sets are provided by the Development Bank of Japan. The FSD includes more than 500 items of balance sheet accounts, profit and loss accounts, and cash flow statements. Moreover, the set contains qualitative information on stock ownership, like the names of the top-10 shareholders and their equity stakes. SLD indicates from which financial institution(s) the firms attract their long-term loans. ${ }^{2}$ So we know the identity of the top-10 equity and loan owners. The FSD data cover more than 2,000 firms listed on the main Japanese stock markets (Tokyo, Osaka, Nagoya, etc.) from 1957 onwards. The SLD data are, however, available only after 1982. We combine both sources and transform all available information into firmyear observations. We checked whether our data reflect the industrial sector of the Japanese economy by mapping our sample on the SNA-classification. Indeed we have a representative sample, although listed firms have an overrepresentation in manufacturing.

The SLD data set restricts our abilities to define long-term loan relations. The SLD-set does not contain loan-specific information. So we define the total number of banks that provided long-term loans in year $t$ as the number of long-term loan banking contacts. For most of those loans it will be likely that the relationship continues up to the next year, but we cannot check whether the same bank actually provides the same long-term loan next year. So suppose that a normal long-term loan will last for three years and a firm has two providers: bank A grants the loan at $t-1$, bank B at time $t$. In our set we observe one bank contact at time $t-1,2$ at times $t$ and $t+1$ and only 1 at time $t+2$.

The initial total number of firm-year observations from 1982 to 1999 is 34,939. In combining the two sets, however, some of the observations are excluded mainly due to inconsistencies between the two data sets. For instance, the outstanding long-term loans

${ }^{2}$ The label financial institution refers to life- and non-life insurance companies as well as public and private banks. Insurance companies and banks are the main long-term funds 
in the SLD data sometimes do not match the balance sheet registration of long-term loans in the FSD source. Also, the source of the long-term loans is in some cases classified by miscellaneous financial institutions, so obviously we cannot identify the number of bank relations. This is also true for the case of classification as foreign banks; that is to say, the data set does not indicate the specific name of the foreign bank (this holds for only 5 per cent of the firms at the maximum). As a result of data screening, we have 20,740 firmyear observations. ${ }^{3}$ Table 2 presents the number of long-term bank relations over the sample period. We show the time series of the number of banking relations for various cases. We distinguish: no loans (0), a single loan (1), 2 to 4 loans, 5 to 7 loans, 8-10 loans, 11-15 loans, and over 16 loans. In the bottom line of Table 2 we give the percentage of single loans (see also Figure 1). Table 2 shows that there is a general increase of the number of loans over time. It also appears that especially the classes with multiple loans (over 10 loans) seem to increase above average.

We also provide the mean and the median of the number of long-term loan relations (Figure 2). As can be seen from Figure 2 the average number of relations decreases from 7.74 in 1982 and reaches a low level of 6.65 in 1989. After 1990, the number moves around 7 except for the sharp decline in 1997. This means that concentration of long-term loans has been gradually promoted towards the bubble period but recovered to the original level after the collapse of the bubble. As shown in Figure 2, however, the median of the number of long-term bank relations is quite stable over the sample period.

suppliers in Japan. Note that we are not able to identify the identity of foreign banks. In our sample foreign banks supply less than five per cent of the loan totals.

${ }^{3}$ It should be noted, however, that the calendar year does not correspond to the actual accounting period of the firm. For example, the firm with the accounting period starting in April 1998 and ending in March 1999 is classified as 1999 in spite that the firm actually operates 9 months in 1998 and only 3 months in 1999. 
Table 2 - Number of bank relations with respect to long-term loans (NBL) by year

\begin{tabular}{|c|c|c|c|c|c|c|c|c|c|c|c|c|c|c|c|c|c|c|c|}
\hline & 1982 & 1983 & 1984 & 1985 & 1986 & 1987 & 1988 & 1989 & 1990 & 1991 & 1992 & 1993 & 1994 & 1995 & 1996 & 1997 & 1998 & 1999 & Total \\
\hline 0 & 158 & 200 & 235 & 258 & 283 & 315 & 355 & 391 & 406 & 404 & 409 & 404 & 416 & 446 & 479 & 502 & 516 & 508 & 6685 \\
\hline 1 & 49 & 59 & 59 & 66 & 70 & 82 & 86 & 90 & 96 & 93 & 69 & 62 & 69 & 65 & 69 & 94 & 103 & 89 & 370 \\
\hline $2 \leq N B L \leq 4$ & 142 & 140 & 154 & 158 & 155 & 149 & 149 & 172 & 187 & 191 & 192 & 207 & 189 & 213 & 220 & 260 & 254 & 244 & 3376 \\
\hline$L \leq 7$ & 162 & 176 & 159 & 160 & 188 & 179 & 184 & 184 & 189 & 202 & 204 & 187 & 207 & 222 & 230 & 236 & 272 & 286 & 3627 \\
\hline $8 \leq \Lambda$ & 117 & 126 & 148 & 144 & 138 & 140 & 126 & 146 & 153 & 159 & 156 & 165 & 140 & 157 & 170 & 168 & 187 & 195 & 2735 \\
\hline $11 \leq N$ & 104 & 90 & 87 & 106 & 89 & 96 & 88 & 85 & 94 & 103 & 111 & 126 & 142 & 143 & 134 & 126 & 138 & 157 & 2019 \\
\hline $16 \leq N B L$ & 47 & 49 & 48 & 43 & 48 & 44 & 42 & 35 & 42 & 51 & 50 & 57 & 54 & 56 & 54 & 49 & 84 & 75 & 928 \\
\hline Total & 779 & 840 & 890 & 935 & 971 & 1005 & 1030 & 1103 & 1167 & 1203 & 1191 & 1208 & 1217 & 1302 & 1356 & 1435 & 1554 & 1554 & 20740 \\
\hline $\begin{array}{r}\text { With long-term } \\
\text { loans } \\
\text { (Percentage) }\end{array}$ & $\begin{array}{r}621 \\
(79,7)\end{array}$ & $\begin{array}{r}640 \\
(76,2)\end{array}$ & 655 & $\begin{array}{r}677 \\
(72,4)\end{array}$ & $(70,9)$ & 690 & $\begin{array}{r}675 \\
(65,5)\end{array}$ & $\begin{array}{r}712 \\
(64,6)\end{array}$ & $\begin{array}{r}761 \\
(65,2)\end{array}$ & 799 & $\begin{array}{r}782 \\
(65,7)\end{array}$ & 804 & $\begin{array}{r}801 \\
(65,8)\end{array}$ & 856 & 877 & 933 & 1038 & 1046 & 14055 \\
\hline $\begin{array}{r}\text { ercentage single } \\
\text { relation }\end{array}$ & 7,9 & 9,2 & 9,0 & 9,7 & 10,2 & 11,9 & 12,7 & 12,6 & 12,6 & 11,6 & 8,8 & 7,7 & 8,6 & 7,6 & 7,9 & 10,1 & 9,9 & 8,5 & 9,7 \\
\hline
\end{tabular}




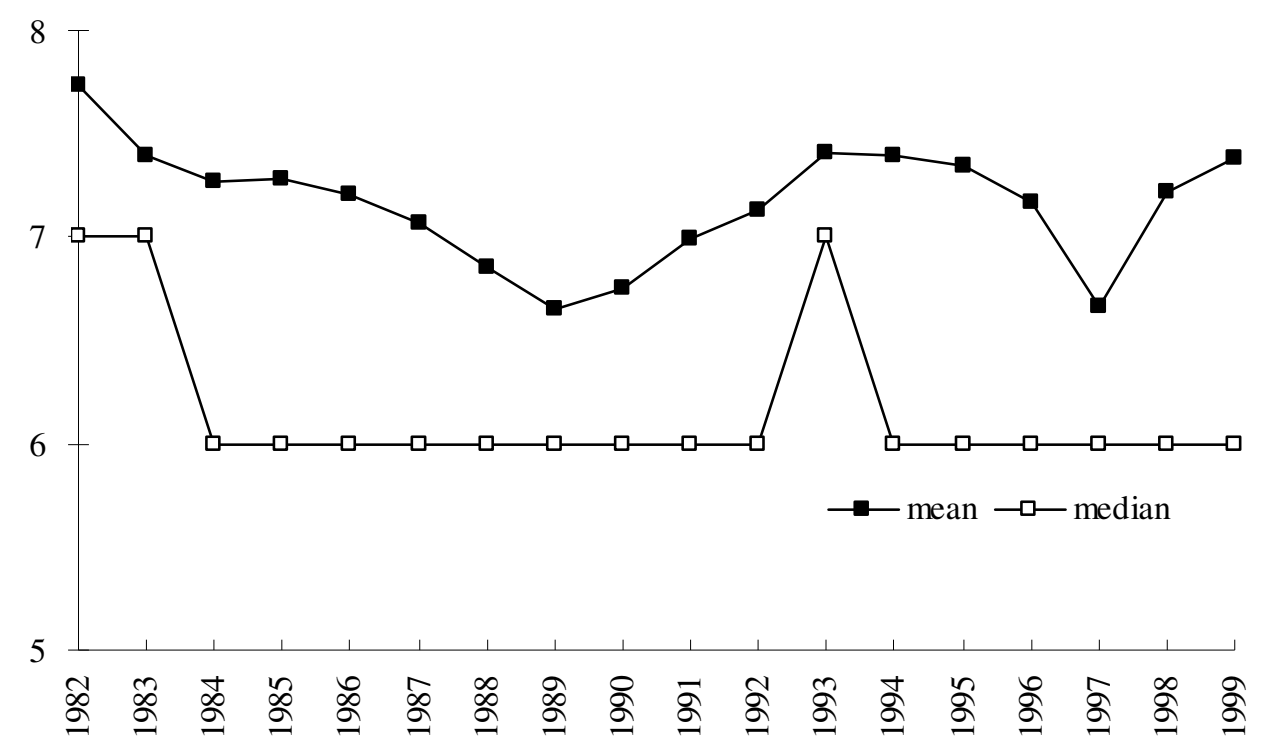

Figure 2. Number of bank relations with respect to long-term loan

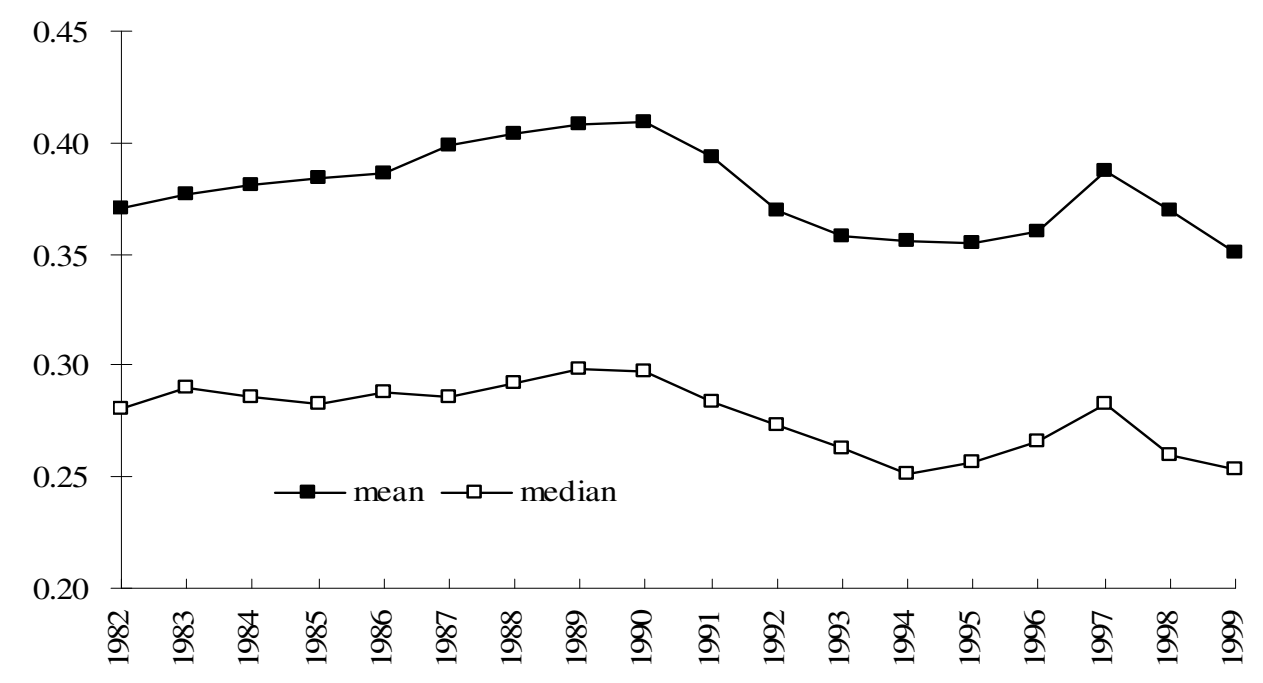

Figure3. Herfindahl index for long-term loans

To end this part of the description we computed the Herfindahl index for long-term loans per firm (see Figure 3). The average of this index increases from 0.370 in 1982 to its maximum of 0.409 in 1990. The same tendency can be seen for the median value. The 
concentration, however, gradually decreases towards its lowest level 0.335 in 1995 and increases again after.

Next to the description of the number of loan contacts we highlight the financial governance of Japanese firms. The Japanese industrial organization differs to a large extent from most western equivalents. Mutual ownership of stock is quite common, especially in the industrial group structures (keiretsu). Within the group structure longlived equity holdings and lender relations are the key financial characteristics. As known, banks play a central role in these business groups, so it is valuable to give some idea of the relation between simultaneous holdings of loans and equity, especially if we want to test the hypothesis that firms that have a main bank relation want fewer banking contacts. In order to consider the relationship between loan activity and equity ownership, we classify our firm-year observations into the following seven categories with respect to a so-called Main Bank Dummy $(M B D)$ :

$M B D_{1}$ : if the largest equity owner is also the largest debt owner;

$M B D_{2}$ : if the largest equity owner resorts under the top-3 debt owners;

$M B D_{3}$ : if the largest equity owner resorts under the top-10 debt owners;

$\mathrm{MBD}_{4}$ : if the largest debt owner resorts under the top-3 equity owners;

$M B D_{5}$ : if the largest debt owner resorts under the top-10 equity owners;

$M B D_{6}$ : if one of the top-3 equity owners resorts under the top-3 debt owners;

$M B D_{7}$ : if one of the top-10 equity owners resorts under the top-10 debt owners.

Table 3 presents the percentage of firms for the above seven cases in our sample by year. As is expected, the first class is the rarest case: a little more than 5 percent of the firmyear observations fall into this class. Note that we consider all equity holders, so also non-bank equity holders. Although equity ownership by banks is highly restricted in Japan $^{4}$, still about half of the firm-year observations are classified in $M B D_{6}$ and about 90

\footnotetext{
${ }^{4}$ In Japan the maximum share of equity holding of a specific firm by a bank is restricted to the maximum of 5 percent since 1987. Before 1987, starting in 1953, this figure was $10 \%$ (see Flath, 1993). For insurance companies the maximum limit is $10 \%$. It should be noted that in our data set the financial institution includes life-insurance companies as
} 
percent of the firm-year observations in our sample fall in the class $M B D_{7}$. How does the governance variable $M B D$ affect the number of bank contacts? First of all, moving from $M B D_{1}$ to $M B D_{3}$ for instance increases the number of multiple bank contacts. Although debt contains also non-loans, the probability of a single lending relation decreases if the largest equity holder moves from the first debt holder to a top-ten debt holder. If a top-ten debt holder moves from a top-ten equity holding position to the single top equity holder one could argue that the relative probability of a single loan relation will become larger. The bank can control the firm not only via the supply of loans, but also as a top equity holder. So the bank is probably willing to offset the liquidity risk the firm faces, lowering the firm's intentions to contact multiple banks. The firm has less costs of asymmetric information and will also prefer a single relationship more (see also Sheard, 1989).

well as private banking companies. The equities held by individual and institutions through trust banks are classified as individual holdings. 
Table 3 The relationship between stockholders and debt suppliers

(1)

top1 share holder $=$ top 1 long-term debt holder
(2)

top1 share

(4) top1 longterm debt
(5) top1 longterm debt
(6) one of the top3 share
(7)

one of the top10 share under top3 under top10 holder resorts holder resorts holder resorts holder resorts long-term long-term under top3 under top10 under top3 under top10 debtholder debtholder share holder share holder long-term long-term

\begin{tabular}{lrrrrrrr}
\hline 1982 & 4.83 & 8.86 & 14.33 & 23.99 & 56.36 & 40.74 & 83.90 \\
1983 & 4.22 & 8.28 & 12.81 & 25.16 & 57.03 & 42.34 & 84.22 \\
1984 & 5.19 & 10.08 & 14.05 & 25.95 & 59.24 & 43.97 & 85.34 \\
1985 & 4.73 & 10.19 & 13.59 & 26.29 & 59.97 & 43.87 & 84.93 \\
1986 & 4.65 & 8.72 & 12.21 & 26.45 & 61.63 & 44.77 & 85.61 \\
1987 & 4.78 & 9.28 & 12.61 & 28.41 & 63.77 & 45.36 & 87.25 \\
1988 & 4.59 & 8.74 & 12.30 & 25.93 & 63.41 & 42.96 & 86.52 \\
1989 & 5.06 & 9.13 & 13.20 & 30.76 & 66.57 & 46.63 & 87.36 \\
1990 & 4.99 & 10.38 & 14.45 & 31.27 & 64.78 & 46.78 & 87.78 \\
1991 & 4.88 & 10.01 & 14.02 & 31.79 & 63.70 & 46.56 & 87.23 \\
1992 & 3.58 & 10.23 & 14.58 & 31.84 & 64.45 & 49.10 & 88.87 \\
1993 & 5.22 & 12.19 & 16.67 & 34.95 & 68.28 & 51.99 & 90.17 \\
1994 & 4.49 & 10.99 & 15.61 & 35.21 & 69.91 & 50.81 & 90.76 \\
1995 & 5.84 & 11.68 & 16.71 & 32.71 & 68.69 & 48.95 & 90.42 \\
1996 & 5.02 & 11.63 & 15.28 & 33.30 & 72.63 & 48.69 & 89.85 \\
1997 & 5.47 & 10.83 & 14.68 & 34.30 & 72.45 & 49.30 & 88.96 \\
1998 & 5.78 & 10.50 & 14.35 & 35.45 & 72.93 & 47.69 & 89.88 \\
1999 & 5.83 & 11.09 & 14.91 & 36.81 & 72.75 & 49.14 & 89.39 \\
\hline Total & 5.01 & 10.27 & 14.35 & 31.16 & 66.23 & 46.99 & 87.96 \\
\hline
\end{tabular}




\section{$4 \quad$ Explaining Japanese multiple bank relationships}

We model the number of bank relations from the perspective of the firm. So we argue that the number of bank contacts is demand driven. One could bring to the fore that supply arguments might interfere: banks might also refuse loan supply. With our dataset we are not able to identify these supply arguments, because we do not have bank-specific information. We argue that banks will probably want to sell their products, especially in the last decade, and be certainly interested in supplying services to large listed firms. Of course banks can control the terms of the contracts, but this will not affect the number of contracts to a large extent.

We model a demand for banking contacts model. Decomposing the total observed variance into inter-firm and temporal variance and leads to the conclusion that we reject the hypothesis that either cross-section or time variance dominates the nature of the observations. So we proceed by explaining firm-year observations instead of using a dynamic panel. We do so in three steps. First we estimate the decision to have a single bank contact versus multiple loans using a simple logit model. Next, we model the decision to opt for multiple loans in more detail by estimating a multinomial logit model. Finally we present evidence on the Herfindahl index of loan concentration using a Tobit model. Given the time-series nature of our data for long-term loans, and the macroeconomic bubble-pattern, we use various sub-samples:

1. 1982-1999;

2. 1982-1989 (the 'bubble' period);

3. 1990-1999 (the post-'bubble’ period).

We use the following variables to explain loan concentration:

- A variable that indicates the size of the firm: total real sales $(S A L)$;

- A variable that indicates profitability $(R O A)$. Here we note that in all our results Tobin's Q did not play a significant role (results available upon request);

- A variable that indicates solvability (debt-to-assets ratio, $D A R$ ); 
- A variables that indicates liquidity (liquid-to-total assets, $L A R$ );

- Variables that indicate alternative financing forms. We use the corporate bonds to debt ratio $(C B R)$ and the short-term loan to debt ratio $(S L R)$;

- A variable that indicates the $R \& D$ activity of the firm: $R \& D$ expense to total sales. Moreover, we include industry dummies (not reported in the tables) and year dummies (not reported in the tables).

- A variable that indicates a relation between top- $x$ loan and top- $y$ equity ownership $\left(M B D_{i}, i=1, \ldots, 7\right)$. We use the 7 indicators as explained above.

First we present a logit-model of the decision to have either a single loan, represented by $Y=1$, or to have multiple loans $(Y=0)$. The results are presented in Table 4 . In Table 4 we give three panels (A, B, and C) that describe the two sub-samples as well as the whole sample period. The rows in each panel give the results for each type of main bank dummy variables, say $M B D_{i}(i=1, \ldots, 7)$ as listed above. The columns give the various estimated parameters of the determinants (see also above). In the last column we give the pseudo-Rsquared and the Correct Prediction Rate $(C P R)$. The numbers of observations used in each sub-sample are denoted at the top of each panel. At the bottom of each panel we also provide the marginal derivatives of the determinants $x$ on the probability of a single relation $P: d P / d x$. We shade the significant estimated parameters at the $5 \%$ confidence level (asymptotic t-values between the brackets below the estimated parameters). 
Table 4 - Estimation results for the binary logit model (single $Y=1$ )

Panel A. Whole period: 1982-99

\begin{tabular}{lrrrrrrrr}
\hline & \multicolumn{1}{c}{$S A L$} & \multicolumn{1}{c}{$R O A$} & \multicolumn{1}{c}{$D A R$} & \multicolumn{1}{c}{$L A R$} & \multicolumn{1}{c}{$C B R$} & \multicolumn{1}{c}{$S L R$} & \multicolumn{1}{c}{$R \& D$} & \multicolumn{1}{c}{$M B D$} \\
\hline (1) $M B D 1$ & 0.00019 & -0.0086 & -0.0412 & 0.0371 & 0.0159 & -0.0007 & -0.0973 & -0.6442 \\
& $(0.85)$ & $(0.96)$ & $(19.6)$ & $(15.4)$ & $(7.81)$ & $(0.30)$ & $(4.26)$ & $(3.67)$ \\
(2) $M B D 2$ & 0.00033 & -0.0081 & -0.0406 & 0.0366 & 0.0165 & -0.0003 & -0.0915 & -1.4830 \\
& $(1.49)$ & $(0.92)$ & $(19.2)$ & $(15.2)$ & $(8.10)$ & $(0.13)$ & $(4.02)$ & $(8.62)$ \\
(3) $M B D 3$ & 0.00047 & -0.0076 & -0.0401 & 0.0360 & 0.0174 & -0.0005 & -0.0795 & -1.9466 \\
& $(2.19)$ & $(0.86)$ & $(19.0)$ & $(15.0)$ & $(8.52)$ & $(0.20)$ & $(3.46)$ & $(11.3)$ \\
(4) $M B D 4$ & 0.00010 & -0.0106 & -0.0396 & 0.0367 & 0.0153 & -0.0013 & -0.0927 & -0.8158 \\
& $(0.45)$ & $(1.22)$ & $(18.8)$ & $(15.2)$ & $(7.48)$ & $(0.55)$ & $(4.07)$ & $(10.6)$ \\
(5) $M B D 5$ & -0.00015 & -0.0087 & -0.0373 & 0.0361 & 0.0142 & -0.0013 & -0.1058 & -1.0356 \\
& $(0.59)$ & $(0.98)$ & $(17.5)$ & $(14.8)$ & $(6.84)$ & $(0.56)$ & $(4.52)$ & $(16.7)$ \\
(6) $M B D 6$ & 0.00021 & -0.0133 & -0.0378 & 0.0357 & 0.0154 & -0.0007 & -0.0924 & -1.5811 \\
& $(0.92)$ & $(1.61)$ & $(17.9)$ & $(14.7)$ & $(7.41)$ & $(0.31)$ & $(4.07)$ & $(20.6)$ \\
(7) $M B D 7$ & -0.00028 & -0.0142 & -0.0295 & 0.0343 & 0.0136 & 0.0009 & -0.1155 & -2.8237 \\
& $(0.95)$ & $(1.61)$ & $(12.7)$ & $(12.9)$ & $(5.89)$ & $(0.36)$ & $(4.44)$ & $(39.6)$ \\
\hline & & & & & & & & \\
\hline (1) $M B D 1$ & 0.0155 & -0.0020 & -0.0038 & 0.0025 & 0.0012 & -0.0001 & -0.0084 & -0.0516 \\
(2) $M B D 2$ & 0.0265 & -0.0019 & -0.0038 & 0.0025 & 0.0012 & -0.0001 & -0.0079 & -0.1215 \\
(3) $M B D 3$ & 0.0383 & -0.0018 & -0.0037 & 0.0024 & 0.0013 & -0.0001 & -0.0069 & -0.1589 \\
(4) $M B D 4$ & 0.0085 & -0.0020 & -0.0037 & 0.0025 & 0.0011 & -0.0001 & -0.0080 & -0.0668 \\
(5) $M B D 5$ & -0.0127 & -0.0018 & -0.0034 & 0.0024 & 0.0010 & -0.0001 & -0.0089 & -0.0842 \\
(6) $M B D 6$ & 0.0159 & -0.0020 & -0.0034 & 0.0023 & 0.0011 & -0.0001 & -0.0077 & -0.1246 \\
(7) $M B D 7$ & -0.0179 & -0.0013 & -0.0021 & 0.0020 & 0.0008 & 0.0000 & -0.0075 & -0.1830 \\
\hline & & & & & & & &
\end{tabular}

Panel B. Bubble period: $1982-89$

\begin{tabular}{lrrrrrrrrr}
\hline (1) $M B D 1$ & 0.00059 & -0.0001 & -0.0501 & 0.0374 & 0.0087 & -0.0045 & -0.1776 & -0.8325 & 0.0901 \\
& $(2.02)$ & $(0.01)$ & $(13.9)$ & $(9.03)$ & $(2.22)$ & $(1.20)$ & $(4.59)$ & $(2.81)$ & 0.8960 \\
(2) $M B D 2$ & 0.00065 & 0.0001 & -0.0499 & 0.0372 & 0.0094 & -0.0040 & -0.1733 & -1.6331 & 0.0980 \\
& $(2.20)$ & $(0.00)$ & $(13.9)$ & $(9.01)$ & $(2.38)$ & $(1.08)$ & $(4.46)$ & $(5.61)$ & 0.8964 \\
(3) $M B D 3$ & 0.00075 & -0.0001 & -0.0499 & 0.0371 & 0.0105 & -0.0044 & -0.1603 & -2.1410 & 0.1080 \\
& $(2.47)$ & $(0.00)$ & $(13.8)$ & $(8.94)$ & $(2.67)$ & $(1.18)$ & $(4.06)$ & $(7.38)$ & 0.8964 \\
(4) $M B D 4$ & 0.00049 & -0.0015 & -0.0490 & 0.0367 & 0.0080 & -0.0052 & -0.1733 & -0.9426 & 0.0996 \\
& $(1.66)$ & $(0.10)$ & $(13.6)$ & $(8.86)$ & $(2.02)$ & $(1.37)$ & $(4.48)$ & $(7.02)$ & 0.8954 \\
(5) $M B D 5$ & 0.00030 & 0.0029 & -0.0449 & 0.0356 & 0.0071 & -0.0047 & -0.1974 & -1.1117 & 0.1124 \\
& $(0.99)$ & $(0.20)$ & $(12.3)$ & $(8.51)$ & $(1.78)$ & $(1.26)$ & $(4.98)$ & $(10.9)$ & 0.8988 \\
(6) $M B D 6$ & 0.00048 & -0.0100 & -0.0480 & 0.0351 & 0.0090 & -0.0041 & -0.1646 & -1.7969 & 0.1367 \\
& $(1.63)$ & $(0.67)$ & $(13.0)$ & $(8.41)$ & $(2.24)$ & $(1.09)$ & $(4.19)$ & $(13.5)$ & 0.8951 \\
(7) $M B D 7$ & 0.00030 & -0.0111 & -0.0354 & 0.0317 & 0.0050 & -0.0033 & -0.1884 & -3.0019 & 0.2350 \\
& $(0.81)$ & $(0.71)$ & $(8.59)$ & $(6.74)$ & $(1.09)$ & $(0.84)$ & $(4.11)$ & $(25.3)$ & 0.9181 \\
\hline & & & & & & & & & \\
\hline (1) $M B D 1$ & 0.0156 & -0.0007 & -0.0034 & 0.0030 & 0.0013 & -0.0001 & -0.0079 & -0.0526 & \\
(2) $M B D 2$ & 0.0267 & -0.0007 & -0.0033 & 0.0030 & 0.0013 & 0.0000 & -0.0074 & -0.1201 & \\
(3) $M B D 3$ & 0.0376 & -0.0006 & -0.0032 & 0.0029 & 0.0014 & 0.0000 & -0.0064 & -0.1562 & \\
(4) $M B D 4$ & 0.0001 & -0.0009 & -0.0032 & 0.0030 & 0.0012 & -0.0001 & -0.0075 & -0.0658 & \\
(5) $M B D 5$ & -0.0119 & -0.0007 & -0.0030 & 0.0029 & 0.0011 & -0.0001 & -0.0084 & -0.0820 &
\end{tabular}


\begin{tabular}{lllllllll} 
(6) $M B D 6$ & 0.0160 & -0.0010 & -0.0029 & 0.0028 & 0.0012 & -0.0001 & -0.0072 & -0.1227 \\
\hline
\end{tabular}

\begin{tabular}{lllllllll} 
(7) $M B D 7$ & -0.0182 & -0.0009 & -0.0019 & 0.0022 & 0.0009 & 0.0001 & -0.0074 & -0.1813 \\
\hline
\end{tabular}

Panel C. Post-Bubbles period: 1990-99

\begin{tabular}{lrrrrrrrrr}
\hline & \multicolumn{1}{c}{$S A L$} & \multicolumn{1}{c}{$R O A$} & \multicolumn{1}{c}{$D A R$} & \multicolumn{1}{c}{$L A R$} & \multicolumn{1}{l}{$C B R$} & \multicolumn{1}{l}{$S L R$} & \multicolumn{1}{l}{$R \& D$} & \multicolumn{1}{c}{$M B D$} & $R^{2} / C P R$ \\
\hline (1) $M B D_{1}$ & -0.00026 & -0.0160 & -0.0363 & 0.0385 & 0.0182 & 0.0014 & -0.0485 & -0.5111 & 0.0556 \\
& $(0.73)$ & $(1.53)$ & $(13.7)$ & $(13.0)$ & $(7.56)$ & $(0.46)$ & $(1.73)$ & $(2.34)$ & 0.9066 \\
(2) $M B D_{2}$ & -0.00008 & -0.0153 & -0.0353 & 0.0377 & 0.0188 & 0.0017 & -0.0417 & -1.3819 & 0.0622 \\
& $(0.24)$ & $(1.47)$ & $(13.4)$ & $(12.7)$ & $(7.75)$ & $(0.56)$ & $(1.50)$ & $(6.47)$ & 0.9069 \\
(3) $M B D_{3}$ & 0.00010 & -0.0143 & -0.0346 & 0.0369 & 0.0195 & 0.0017 & -0.0300 & -1.8316 & 0.0696 \\
& $(0.31)$ & $(1.38)$ & $(13.1)$ & $(12.5)$ & $(8.06)$ & $(0.56)$ & $(1.07)$ & $(8.57)$ & 0.9066 \\
(4) $M B D_{4}$ & -0.00035 & -0.0178 & -0.0346 & 0.0383 & 0.0179 & 0.0009 & -0.0445 & -0.7707 & 0.0635 \\
& $(0.99)$ & $(1.78)$ & $(13.1)$ & $(12.8)$ & $(7.38)$ & $(0.29)$ & $(1.60)$ & $(8.08)$ & 0.9064 \\
(5) $M B D_{5}$ & -0.00068 & -0.0172 & -0.0333 & 0.0380 & 0.0168 & 0.0008 & -0.0509 & -1.0050 & 0.0740 \\
& $(1.75)$ & $(1.66)$ & $(12.5)$ & $(12.6)$ & $(6.85)$ & $(0.26)$ & $(1.80)$ & $(12.7)$ & 0.9071 \\
(6) $M B D_{6}$ & -0.00019 & -0.0174 & -0.0328 & 0.0373 & 0.0178 & 0.0015 & -0.0495 & -1.4747 & 0.0897 \\
& $(0.55)$ & $(1.83)$ & $(12.5)$ & $(12.5)$ & $(7.26)$ & $(0.50)$ & $(1.80)$ & $(15.4)$ & 0.9077 \\
(7) $M B D_{7}$ & -0.00104 & -0.0179 & -0.0268 & 0.0366 & 0.0168 & 0.0033 & -0.0721 & -2.7701 & 0.1675 \\
& $(2.20)$ & $(1.71)$ & $(9.30)$ & $(11.2)$ & $(6.23)$ & $(1.04)$ & $(2.30)$ & $(30.2)$ & 0.9149 \\
\hline & & & & & & & & & \\
\hline (1) $M B D 1$ & -0.0203 & -0.0013 & -0.0029 & 0.0031 & 0.0014 & 0.0001 & -0.0038 & -0.0405 & \\
(2) $M B D 2$ & -0.0064 & -0.0012 & -0.0028 & 0.0030 & 0.0015 & 0.0001 & -0.0033 & -0.1088 & \\
(3) $M B D 3$ & 0.0081 & -0.0011 & -0.0027 & 0.0029 & 0.0015 & 0.0001 & -0.0023 & -0.1431 & \\
(4) $M B D 4$ & -0.0278 & -0.0014 & -0.0027 & 0.0030 & 0.0014 & 0.0001 & -0.0035 & -0.0605 & \\
(5) $M B D 5$ & -0.0523 & -0.0013 & -0.0026 & 0.0029 & 0.0013 & 0.0001 & -0.0039 & -0.0775 & \\
(6) $M B D 6$ & -0.0143 & -0.0013 & -0.0025 & 0.0028 & 0.0014 & 0.0001 & -0.0038 & -0.1119 & \\
(7) $M B D 7$ & -0.0661 & -0.0011 & -0.0017 & 0.0023 & 0.0011 & 0.0002 & -0.0046 & -0.1765 &
\end{tabular}

$C B R=$ corporate bonds to total debt;

$D A R=$ debt-to-assets ratio;

$L A R=$ liquid assets to total assets ratio;

$M B D_{i}=$ main-bank dummy variable $=1$ if a main bank loan supplies are also a main equity holders (subscript $i$ indicates the relative importance both in loan and equity holding, see Section 3);

$N B L=$ number of long-term bank loans;

$R O A=$ return on assets (profits after tax / the average of the total asset at the beginning and the end of period);

$R \& D=\mathrm{R} \& \mathrm{D}$ expenditure to total sales;

$S A L=$ total sales, corresponding probability $d P / d x$ is in terms of $10^{3}$;

$S L R=$ short-term loans to total debt. 
Table 4 shows that a higher debt-to-assets ratio $(D A R)$ decreases the probability of a single loan relation in all cases. This is a natural effect: more debt implies a higher loan demand, which increases the probability of multiple loans. It is also clear that a higher liquid to total assets ratio $(L A R)$ increases the probability of a single bank relation. Firms with relatively more liquid assets do not need liquidity insurance and rely on a single bank. Table 4 also shows that variables that represent the size of the firm $(S A L)$ and profitability $(R O A)$ do not have a systematic impact on loan decisions. Of the alternative financing forms (short-term loans $S L R$ and the corporate bond to total debt ratio $C B R$ ) only the corporate bond to debt ratio has a significant impact on the single versus multiple loan relation decision. A higher value of $C B R$ indicates two features: more bonds relative to loans will increase the probability of a single loan by itself. But secondly, as explained above, corporate bonds also signal quality. A higher bond rating reduces the need for multiple banking contacts. All the main bank dummies $M B D_{i}$ have a significant negative impact on the probability of a single bank relation. The firm might use a main bank relation as a signal of quality in attracting other debt suppliers' attention. As known (see Weinstein and Yafeh,1998)) main banks charge higher interest rates, which might force firms to look for cheaper alternatives. On the other hand, it might be in the interest of the main bank as an equity holder to have some liquidity insurance. If we compare the results of the $M B D_{i}$-lines one should note that for the cases where the bank is the largest equity holder, the probability of single borrowing relations decreases with a more modest position of the bank as a top-debt supplier. The other way round, if the bank is the largest supplier of debt, the probability of a single relation increases if the bank becomes a more important equity holder. So there are two effects: a main bank relation leads to a larger probability of multiple banking contacts, but equity concentration leads to a relatively higher probability of a single loan.

Comparing the bubble and post-bubble period one can observe that there are no real large differences in terms of marginal derivatives. An increase of the debt-to-assets ratio by $1 \%$ decreases the probability of a single relation in the bubble period by $0.5 \%$ and by $0.3 \%$ in the post-bubble period. The other derivatives are comparable across sub-periods. The most striking difference is the impact of R\&D-expenses. In the bubble period more $R \& D$ 
expenses decrease the probability of a single relation: this supports the BhattacharyaChiesa hypothesis (see Section 2). In the post-bubble period this impact of R\&D expenses vanishes. The R-squared is around 0.1 , but the correct prediction rate is around 90 percent for all models. In general, we can conceive the relatively stable relationship between the several determinants and the single-multiple decision irrespective of the choice of $M B D_{i}{ }^{\prime}$ 's.

Next we analyze the decision of multiple loan contacts further (see for a similar approach Detragiache et al., 2000). That is to say, once firms decided to have multiple loans, how many relations do they have? We model five classes:

1. 2-4 relationships $(Y=0)$;

2. 5-7 relationships $(Y=1)$;

3. 8 -10 relationships $(Y=2)$;

4. $11-15$ relationships $(Y=3)$;

5. 16 and more relationships $(Y=4)$.

Table 5 contains the results of the estimated multinomial logit model. We use the same structure as presented in Table 4 again. For each panel we present the estimated parameters and the $d P / d x$ values. In estimating the model, the parameters for $Y=0$ (the smallest number of relations, 2-4 relations) are normalized to zero. So, all parameters should be interpreted as changes from the base case $Y=0$. We include only the results for one of the main bank relation variables $M B D_{3}$. 
Table 5 - Estimation results multinomial logit-model for number of bank relations

Panel A. Whole period: $1982-1999, R^{2}=0.2423$

\begin{tabular}{|c|c|c|c|c|c|c|c|c|}
\hline & $S A L$ & $R O A$ & $D A R$ & $L A R$ & $C B R$ & $S L R$ & $R \& D$ & $M B D_{3}$ \\
\hline (2) $5-7$ & $\begin{array}{r}-0.00090 \\
(2.40)\end{array}$ & $\begin{array}{r}-0.0108 \\
(1.57)\end{array}$ & $\begin{array}{r}0.0217 \\
(12.3)\end{array}$ & $\begin{array}{r}-0.0180 \\
(9.29)\end{array}$ & $\begin{array}{r}-0.0065 \\
(3.36)\end{array}$ & $\begin{array}{r}0.0002 \\
(0.11)\end{array}$ & $\begin{array}{r}-0.0277 \\
(1.56)\end{array}$ & $\begin{array}{r}0.6715 \\
(8.12)\end{array}$ \\
\hline (3) $8-10$ & $\begin{array}{r}0.00045 \\
(1.30)\end{array}$ & $\begin{array}{r}0.0177 \\
(2.29)\end{array}$ & $\begin{array}{r}0.0469 \\
(23.2)\end{array}$ & $\begin{array}{r}-0.0364 \\
(17.1)\end{array}$ & $\begin{array}{r}-0.0088 \\
(4.08)\end{array}$ & $\begin{array}{r}-0.0077 \\
(3.60)\end{array}$ & $\begin{array}{r}0.0057 \\
(0.30)\end{array}$ & $\begin{array}{r}0.9979 \\
(11.6)\end{array}$ \\
\hline (4) $11-15$ & $\begin{array}{r}0.00231 \\
(7.28)\end{array}$ & $\begin{array}{r}0.0100 \\
(1.17)\end{array}$ & $\begin{array}{r}0.0580 \\
(25.1)\end{array}$ & $\begin{array}{r}-0.0386 \\
(16.5)\end{array}$ & $\begin{array}{r}-0.0062 \\
(2.57)\end{array}$ & $\begin{array}{r}-0.0107 \\
(4.41)\end{array}$ & $\begin{array}{r}-0.0006 \\
(0.03)\end{array}$ & $\begin{array}{r}1.3116 \\
(14.6)\end{array}$ \\
\hline (5) $16-$ & $\begin{array}{r}0.00304 \\
(9.18) \\
\end{array}$ & $\begin{array}{r}0.0214 \\
(1.92) \\
\end{array}$ & $\begin{array}{r}0.0817 \\
(24.2) \\
\end{array}$ & $\begin{array}{r}-0.0584 \\
(19.7) \\
\end{array}$ & $\begin{array}{r}0.0014 \\
(0.44) \\
\end{array}$ & $\begin{array}{r}-0.0049 \\
(1.51) \\
\end{array}$ & $\begin{array}{r}0.1223 \\
(4.66) \\
\end{array}$ & $\begin{array}{r}1.6701 \\
(15.1) \\
\end{array}$ \\
\hline (1) $2-4$ & -0.0593 & -0.0006 & -0.0069 & 0.0052 & 0.0011 & 0.0008 & 0.0006 & -0.1654 \\
\hline (2) $5-7$ & -0.3494 & -0.0040 & -0.0022 & 0.0012 & -0.0005 & 0.0010 & -0.0077 & -0.0082 \\
\hline (3) $8-10$ & -0.0001 & 0.0028 & 0.0029 & -0.0025 & -0.0009 & -0.0008 & 0.0007 & 0.0476 \\
\hline (4) $11-15$ & 0.2647 & 0.0007 & 0.0034 & -0.0019 & -0.0002 & -0.0010 & -0.0011 & 0.0749 \\
\hline (5) 16- & 0.1494 & 0.0010 & 0.0028 & -0.0020 & 0.0004 & 0.0000 & 0.0075 & 0.0510 \\
\hline
\end{tabular}

Panel B. Bubble period: $1982-1989, R^{2}=0.2804$

\begin{tabular}{|c|c|c|c|c|c|c|c|c|c|}
\hline (2) & $5-7$ & $\begin{array}{r}-0.00146 \\
(2.27)\end{array}$ & $\begin{array}{r}-0.0355 \\
(2.62)\end{array}$ & $\begin{array}{r}0.0277 \\
(8.45)\end{array}$ & $\begin{array}{r}-0.0191 \\
(5.26)\end{array}$ & $\begin{array}{r}0.0030 \\
(0.69)\end{array}$ & $\begin{array}{r}-0.0015 \\
(0.46)\end{array}$ & $\begin{array}{r}0.0180 \\
(0.59)\end{array}$ & $\begin{array}{r}0.9220 \\
(6.32)\end{array}$ \\
\hline (3) & $8-10$ & $\begin{array}{r}0.00020 \\
(0.35)\end{array}$ & $\begin{array}{r}-0.0086 \\
(0.63)\end{array}$ & $\begin{array}{r}0.0557 \\
(15.0)\end{array}$ & $\begin{array}{r}-0.0411 \\
(10.4)\end{array}$ & $\begin{array}{r}0.0122 \\
(2.57)\end{array}$ & $\begin{array}{r}-0.0016 \\
(0.47)\end{array}$ & $\begin{array}{r}0.0112 \\
(0.32)\end{array}$ & $\begin{array}{r}1.3036 \\
(8.67)\end{array}$ \\
\hline (4) & $11-15$ & $\begin{array}{r}0.00182 \\
(3.33)\end{array}$ & $\begin{array}{r}-0.0165 \\
(1.03)\end{array}$ & $\begin{array}{r}0.0711 \\
(16.2)\end{array}$ & $\begin{array}{r}-0.0439 \\
(10.1)\end{array}$ & $\begin{array}{r}0.0053 \\
(0.94)\end{array}$ & $\begin{array}{r}-0.0173 \\
(4.15)\end{array}$ & $\begin{array}{r}0.0226 \\
(0.58)\end{array}$ & $\begin{array}{r}1.5435 \\
(9.61)\end{array}$ \\
\hline (5) & $16-$ & $\begin{array}{r}0.00221 \\
(3.91)\end{array}$ & $\begin{array}{r}0.0116 \\
(0.59)\end{array}$ & $\begin{array}{r}0.0973 \\
(15.8)\end{array}$ & $\begin{array}{r}-0.0714 \\
(13.4)\end{array}$ & $\begin{array}{r}0.0340 \\
(4.95)\end{array}$ & $\begin{array}{r}0.0033 \\
(0.62)\end{array}$ & $\begin{array}{r}0.1938 \\
(4.26)\end{array}$ & $\begin{array}{r}1.7377 \\
(8.69)\end{array}$ \\
\hline (1) & $2-4$ & 0.0275 & 0.0035 & -0.0079 & 0.0055 & -0.0013 & 0.0007 & -0.0046 & -0.1971 \\
\hline (2) & $5-7$ & -0.4092 & -0.0060 & -0.0025 & 0.0018 & -0.0009 & 0.0005 & -0.0010 & 0.0089 \\
\hline (3) & $8-10$ & 0.0210 & 0.0013 & 0.0032 & -0.0028 & 0.0011 & 0.0004 & -0.0035 & 0.0715 \\
\hline (4) & $11-15$ & 0.2415 & -0.0004 & 0.0040 & -0.0020 & -0.0005 & -0.0021 & -0.0014 & 0.0758 \\
\hline (5) & 16- & 0.1192 & 0.0016 & 0.0032 & -0.0025 & 0.0016 & 0.0005 & 0.0105 & 0.0409 \\
\hline
\end{tabular}

Panel C. Post-Bubble period: $1990-1999, R^{2}=0.2424$

\begin{tabular}{|c|c|c|c|c|c|c|c|c|c|}
\hline (2) & $5-7$ & $\begin{array}{r}-0.00059 \\
(1.25)\end{array}$ & $\begin{array}{r}0.0027 \\
(0.35)\end{array}$ & $\begin{array}{r}0.0198 \\
(9.28)\end{array}$ & $\begin{array}{r}-0.0196 \\
(8.51)\end{array}$ & $\begin{array}{r}-0.0087 \\
(3.98)\end{array}$ & $\begin{array}{r}0.0008 \\
(0.33)\end{array}$ & $\begin{array}{r}-0.0519 \\
(2.32)\end{array}$ & $\begin{array}{r}0.5509 \\
(5.43)\end{array}$ \\
\hline (3) & $8-10$ & $\begin{array}{r}0.00058 \\
(1.31)\end{array}$ & $\begin{array}{r}0.0331 \\
(3.45)\end{array}$ & $\begin{array}{c}0.0442 \\
(18.02)\end{array}$ & $\begin{array}{r}-0.0351 \\
(13.85)\end{array}$ & $\begin{array}{r}-0.0144 \\
(5.80)\end{array}$ & $\begin{array}{r}-0.0101 \\
(3.69)\end{array}$ & $\begin{array}{r}0.0092 \\
(0.39)\end{array}$ & $\begin{array}{r}0.8443 \\
(8.00)\end{array}$ \\
\hline (4) & $11-15$ & $\begin{array}{r}0.00261 \\
(6.49)\end{array}$ & $\begin{array}{r}0.0267 \\
(2.58)\end{array}$ & $\begin{array}{c}0.0529 \\
(19.05)\end{array}$ & $\begin{array}{r}-0.0378 \\
(13.58)\end{array}$ & $\begin{array}{r}-0.0082 \\
(3.04)\end{array}$ & $\begin{array}{r}-0.0069 \\
(2.27)\end{array}$ & $\begin{array}{r}-0.0089 \\
(0.35)\end{array}$ & $\begin{array}{r}1.2121 \\
(11.1)\end{array}$ \\
\hline (5) & 16- & $\begin{array}{r}0.00351 \\
(8.39)\end{array}$ & $\begin{array}{r}0.0288 \\
(2.15)\end{array}$ & $\begin{array}{c}0.0764 \\
(18.55)\end{array}$ & $\begin{array}{r}-0.0526 \\
(14.71)\end{array}$ & $\begin{array}{r}-0.0070 \\
(1.84)\end{array}$ & $\begin{array}{r}-0.0084 \\
(2.01)\end{array}$ & $\begin{array}{r}0.0829 \\
(2.50)\end{array}$ & $\begin{array}{r}1.6235 \\
(12.1)\end{array}$ \\
\hline (1) & $2-4$ & -0.1115 & -0.0031 & -0.0065 & 0.0053 & 0.00 & 0.0008 & 0.0031 & -0.1481 \\
\hline (2) & $5-7$ & -0.3133 & -0.0030 & -0.0021 & 0.0006 & -0.0004 & 0.0012 & -0.0117 & -0.0164 \\
\hline (3) & $8-10$ & -0.0199 & 0.0037 & 0.0029 & -0.0023 & -0.0014 & -0.0013 & 0.0036 & 0.0348 \\
\hline (4) & $11-15$ & 0.2817 & 0.0016 & 0.0031 & -0.0019 & -0.0001 & -0.0004 & -0.0006 & 0.0760 \\
\hline (5) & $16-$ & 0.1629 & 0.0007 & 0.0026 & -0.0016 & 0.0001 & -0.0002 & 0.0056 & 0.0536 \\
\hline
\end{tabular}


Table 5 shows that in most cases there is a split between less than and more than 8 banking contacts. Take for example the impact of the debt-to-assets ratio $(D A R)$. A lower solvability (higher $D A R$ ) decreases the probability of having less than 8 contacts, and increases the probabilities of the large contact classes. For the liquid assets ratio (LAR) the reverse holds. Liquidity-rich firms have higher probabilities of having up to 8 bank contacts. For the main-bank dummy variable $M B D_{3}$ we find that the probability of multiple banking contacts (more than 8) increases. Apart from these main three determinants, we now also observe that size ( $S A L)$, profitability (ROA), and the financing alternatives matter in some cases. We find that larger firms want more bank relations, especially for the large numbers of banking contacts (more than 11). There is also some evidence that in the post-bubble period profitability matters. More profitable firms want more bank relations; this finding implies that most of the loss-making firms will tend to have fewer bank relations. Alternative financing forms (the availability of corporate bonds, $C B R$, and short-term loans $S L R$ ) tend to make firms opt for a moderate (up to 8 loan contacts) or extensive number of banking relations. For the first group there could be substitution of financing means, while for the latter group the signaling function might be relevant. R\&D-intensive firms tend to have a larger probability of having multiple relations (more than 16). We do not find striking differences between the bubble and post-bubble period in this model. The previous results relate to the discrete lending choice. Next we use a continuous variable as a dependent variable, the Herfindahl-index, as a robustness check. The Herfindahl index is limited in range (by definition in the interval $[0,1])$. Prior to estimating the model we transformed the original index by taking the logarithm and multiplying it by -1 . By this transformation the dependent variable will loose its upper bound. After this transformation we apply an ordinary Tobit model with a lower truncation at zero. Table 6 gives the estimation results. It should be noted that a larger value of the dependent variable implies a lower concentration (multiple loan contacts). A plus sign in the table therefore indicates that an increase of the determining variable will lead to more banking relations. Table 6 includes the same panels and determinants as before. We give the results for all our main bank relation variables $M B D_{i}$ $(i=1, \ldots 7)$. 
Table 6 - Estimation results: Tobit-model for the Herfindahl index

Panel A. Whole period: 1982-99

\begin{tabular}{|c|c|c|c|c|c|c|c|c|c|}
\hline & $S A L$ & $R O A$ & $D A R$ & $L A R$ & $C B R$ & $S L R$ & $R \& D$ & $M B D$ & $L H / \square$ \\
\hline \multirow{2}{*}{ (1) $M B D_{1}$} & 0.00033 & 0.0068 & 0.0122 & -0.0102 & -0.0024 & -0.0003 & 0.0168 & 0.1414 & -14859.0 \\
\hline & (7.28) & $(4.58)$ & $(30.7)$ & (23.7) & (5.36) & $(0.71)$ & $(4.02)$ & $(5.29)$ & 0.6831 \\
\hline \multirow[t]{2}{*}{ (2) $M B D_{2}$} & 0.00029 & 0.0066 & 0.0121 & -0.0102 & -0.0026 & -0.0005 & 0.0149 & 0.2373 & -14797.7 \\
\hline & (6.37) & $(4.51)$ & $(30.5)$ & (23.8) & $(5.74)$ & (1.03) & $(3.58)$ & (12.3) & 0.6802 \\
\hline \multirow{2}{*}{ (3) $M B D_{3}$} & 0.00024 & 0.0066 & 0.0119 & -0.0101 & -0.0029 & -0.0004 & 0.0121 & 0.3194 & -14694.9 \\
\hline & (5.24) & $(4.53)$ & (30.4) & (23.8) & (6.54) & (0.96) & (2.93) & (19.0) & 0.6751 \\
\hline \multirow{2}{*}{ (4) $M B D_{4}$} & 0.00036 & 0.0068 & 0.0120 & -0.0102 & -0.0023 & -0.0003 & 0.0164 & 0.1355 & -14815.8 \\
\hline & (7.77) & (4.64) & $(30.2)$ & $(23.7)$ & (5.17) & $(0.58)$ & (3.94) & (10.7) & 0.6812 \\
\hline \multirow[t]{2}{*}{ (5) $M B D_{5}$} & 0.00040 & 0.0065 & 0.0116 & -0.0101 & -0.0021 & -0.0002 & 0.0181 & 0.2325 & -14702.7 \\
\hline & (8.86) & $(4.44)$ & $(29.4)$ & (23.7) & (4.66) & $(0.52)$ & $(4.37)$ & (18.5) & 0.6762 \\
\hline \multirow[t]{2}{*}{ (6) $M B D_{6}$} & 0.00031 & 0.0069 & 0.0116 & -0.0100 & -0.0025 & -0.0005 & 0.0165 & 0.2823 & -14581.4 \\
\hline & (6.94) & (4.77) & $(29.7)$ & (23.7) & (5.53) & (1.06) & (4.01) & (24.3) & 0.6705 \\
\hline \multirow[t]{2}{*}{ (7) $M B D_{7}$} & 0.00038 & 0.0055 & 0.0096 & -0.0090 & -0.0017 & -0.0006 & 0.0166 & 0.9495 & -13488.7 \\
\hline & (9.08) & (4.03) & (26.1) & (22.7) & (4.11) & (1.54) & (4.31) & (53.5) & 0.6260 \\
\hline
\end{tabular}

Panel B. Bubble period: 1982-89

\begin{tabular}{lrrrrrrrrr}
\hline (1) $M B D_{1}$ & 0.00004 & 0.0062 & 0.0154 & -0.0119 & 0.0020 & 0.0014 & 0.0273 & 0.1807 & -5533.0 \\
& $(0.49)$ & $(2.29)$ & $(21.9)$ & $(15.6)$ & $(2.11)$ & $(1.97)$ & $(3.87)$ & $(4.18)$ & 0.6664 \\
(2) $M B D_{2}$ & 0.00001 & 0.0062 & 0.0154 & -0.0119 & 0.0019 & 0.0013 & 0.0257 & 0.2347 & -5515.1 \\
& $(0.09)$ & $(2.28)$ & $(21.9)$ & $(15.7)$ & $(2.01)$ & $(1.80)$ & $(3.66)$ & $(7.31)$ & 0.6643 \\
(3) $M B D_{3}$ & -0.00005 & 0.0062 & 0.0153 & -0.0120 & 0.0015 & 0.0014 & 0.0238 & 0.3163 & -5476.3 \\
& $(0.58)$ & $(2.29)$ & $(22.0)$ & $(15.8)$ & $(1.54)$ & $(1.91)$ & $(3.41)$ & $(11.5)$ & 0.6595 \\
(4) $M B D_{4}$ & 0.00006 & 0.0062 & 0.0152 & -0.0118 & 0.0020 & 0.0015 & 0.0275 & 0.1190 & -5525.5 \\
& $(0.81)$ & $(2.29)$ & $(21.6)$ & $(15.5)$ & $(2.15)$ & $(2.08)$ & $(3.90)$ & $(5.70)$ & 0.6658 \\
(5) $M B D_{5}$ & 0.00010 & 0.0054 & 0.0145 & -0.0117 & 0.0020 & 0.0014 & 0.0308 & 0.2115 & -5482.7 \\
& $(1.34)$ & $(1.98)$ & $(20.7)$ & $(15.4)$ & $(2.15)$ & $(1.98)$ & $(4.41)$ & $(10.9)$ & 0.6609 \\
(6) $M B D_{6}$ & 0.00003 & 0.0070 & 0.0148 & -0.0116 & 0.0017 & 0.0013 & 0.0257 & 0.2604 & -5443.6 \\
& $(0.40)$ & $(2.62)$ & $(21.4)$ & $(15.4)$ & $(1.86)$ & $(1.78)$ & $(3.70)$ & $(14.1)$ & 0.6564 \\
& & & & & \\
(7) $M B D_{7}$ & 0.00008 & 0.0049 & 0.0119 & -0.0102 & 0.0024 & 0.0009 & 0.0224 & 0.8790 & -5004.1 \\
& $(1.09)$ & $(1.94)$ & $(18.1)$ & $(14.5)$ & $(2.78)$ & $(1.36)$ & $(3.45)$ & $(33.3)$ & 0.6109 \\
\hline
\end{tabular}


Panel C. Post-Bubble period: 1990-99

\begin{tabular}{|c|c|c|c|c|c|c|c|c|c|}
\hline (1) $M B D_{1}$ & $\begin{array}{r}0.00048 \\
(8.51)\end{array}$ & $\begin{array}{r}0.0075 \\
(4.25)\end{array}$ & $\begin{array}{r}0.0108 \\
(22.2)\end{array}$ & $\begin{array}{r}-0.0098 \\
(18.7)\end{array}$ & $\begin{array}{r}-0.0036 \\
(6.94)\end{array}$ & $\begin{array}{r}-0.0011 \\
(1.99)\end{array}$ & $\begin{array}{r}0.0125 \\
(2.40)\end{array}$ & $\begin{array}{r}0.1192 \\
(3.52)\end{array}$ & $\begin{array}{r}-9252.7 \\
0.6875\end{array}$ \\
\hline (2) $M B D_{2}$ & $\begin{array}{r}0.00043 \\
(7.67)\end{array}$ & $\begin{array}{r}0.0073 \\
(4.15)\end{array}$ & $\begin{array}{r}0.0106 \\
(22.0)\end{array}$ & $\begin{array}{r}-0.0097 \\
(18.6)\end{array}$ & $\begin{array}{r}-0.0038 \\
(7.32)\end{array}$ & $\begin{array}{r}-0.0013 \\
(2.24)\end{array}$ & $\begin{array}{r}0.0104 \\
(2.01)\end{array}$ & $\begin{array}{r}0.2384 \\
(9.90)\end{array}$ & $\begin{array}{r}-9210.1 \\
0.6841\end{array}$ \\
\hline (3) $M B D_{3}$ & $\begin{array}{r}0.00038 \\
(6.76)\end{array}$ & $\begin{array}{r}0.0072 \\
(4.15)\end{array}$ & $\begin{array}{r}0.0105 \\
(21.8)\end{array}$ & $\begin{array}{r}-0.0096 \\
(18.6)\end{array}$ & $\begin{array}{r}-0.0041 \\
(7.99)\end{array}$ & $\begin{array}{r}-0.0013 \\
(2.23)\end{array}$ & $\begin{array}{r}0.0073 \\
(1.43)\end{array}$ & $\begin{array}{r}0.3207 \\
(15.1)\end{array}$ & $\begin{array}{r}-9145.4 \\
0.6789\end{array}$ \\
\hline (4) $M B D_{4}$ & $\begin{array}{r}0.00050 \\
(8.88)\end{array}$ & $\begin{array}{r}0.0076 \\
(4.31)\end{array}$ & $\begin{array}{r}0.0106 \\
(21.8)\end{array}$ & $\begin{array}{r}-0.0097 \\
(18.6)\end{array}$ & $\begin{array}{r}-0.0035 \\
(6.76)\end{array}$ & $\begin{array}{r}-0.0011 \\
(1.90)\end{array}$ & & $\begin{array}{r}0.1415 \\
(8.93)\end{array}$ & $\begin{array}{r}-9219.1 \\
0.6850\end{array}$ \\
\hline (5) $M B D_{5}$ & $\begin{array}{r}0.00055 \\
(9.83)\end{array}$ & $\begin{array}{r}0.0074 \\
(4.26)\end{array}$ & $\begin{array}{r}0.0104 \\
(21.6)\end{array}$ & $\begin{array}{r}-0.0097 \\
(18.7)\end{array}$ & $\begin{array}{r}-0.0032 \\
(6.19)\end{array}$ & $\begin{array}{r}-0.0010 \\
(1.75)\end{array}$ & $\begin{array}{r}0.0126 \\
(2.45)\end{array}$ & $\begin{array}{r}0.2410 \\
(14.7)\end{array}$ & $\begin{array}{r}-9151.6 \\
0.6801\end{array}$ \\
\hline (6) $M B D_{6}$ & $\begin{array}{r}0.00045 \\
(8.15)\end{array}$ & $\begin{array}{r}0.0073 \\
(4.24)\end{array}$ & $\begin{array}{r}0.0103 \\
(21.5)\end{array}$ & $\begin{array}{r}-0.0096 \\
(18.7)\end{array}$ & $\begin{array}{r}-0.0036 \\
(7.04)\end{array}$ & $\begin{array}{r}-0.0013 \\
(2.33)\end{array}$ & $\begin{array}{r}0.0131 \\
(2.58)\end{array}$ & $\begin{array}{r}0.2919 \\
(19.6)\end{array}$ & $\begin{array}{r}-9069.4 \\
0.6737\end{array}$ \\
\hline (7) $M B D_{7}$ & $\begin{array}{r}0.00053 \\
(10.2)\end{array}$ & $\begin{array}{r}0.0062 \\
(3.84)\end{array}$ & $\begin{array}{r}0.0088 \\
(19.5)\end{array}$ & $\begin{array}{r}-0.0086 \\
(17.9)\end{array}$ & $\begin{array}{r}-0.0028 \\
(5.89)\end{array}$ & $\begin{array}{r}-0.0014 \\
(2.68)\end{array}$ & $\begin{array}{r}0.0147 \\
(3.07)\end{array}$ & $\begin{array}{r}0.9950 \\
(41.7)\end{array}$ & $\begin{array}{r}-8415.9 \\
0.6302\end{array}$ \\
\hline
\end{tabular}

The results in Table 6 confirm the results shown in Tables 4 and 5. Table 6 shows that an increase in sales ( $S A L$, representing size) leads to a lower concentration of loans in the post-bubble period only. Higher profitability $(R O A)$ implies more banking contacts, especially after 1990 . Both the impact of size and profitability did not come to the fore as prominently as in the discrete choice models. As in Tables 4 and 5, a higher debt-toassets $(D A R)$ and a lower liquidity ( $L A R)$ lead to more banking relations. With respect to the alternative financing forms we now find some differences between the bubble and post-bubble periods. It seems that both corporate bonds $(C B R)$ and short-term loans $(S L R)$ developed from complementary assets into true substitutes after 1990. For the corporate bond market this result coincides with the institutional observation that corporate bonds developed from loan-like assets into alternative market financing forms. As before having a main-bank relation leads to a lower concentration of loans. Especially, in the postbubble period an equity-holding bank relation leads to fewer banking contacts. Finally more R\&D-intensive firms tend to have a lower loan concentration. 


\section{$5 \quad$ Summary and conclusions}

In this paper we analyze the number of long-term bank relations that Japanese listed firms maintain. Japanese firms have a median of 6 long-term bank relations (while the mean is about 7 relations). Compared to other countries this is about the average value observed. But Japanese listed firms show a rather large variation around this median value. We present an overview of the rather extensive literature in the field of the optimal number of creditors. From this literature we retrieve a set of likely candidate variables that might have an impact on the number of bank relations. We focus on long-term loans, since these loans play a crucial role in the functioning of the Japanese economy. We estimate discrete choice models of the decision for single versus multiple relations, the decision to have a number of bank relations in certain classes (in a multinomial logit model) and a model with a continuous measurement of the loan concentration (as measured by the Herfindahl index).

Our general conclusions are as follows. Size, profitability, solvability, liquidity, and alternative financing forms determine the number of banking contacts. These variables are standard determinants of the number of bank relations. Our results support especially the liquidity insurance argument to have multiple relations, as well as the impact of solvability. We show that size and profitability matter in explaining the Herfindahl-index of loan concentration. We pay special attention to the impact of Japanese corporate governance by including indicators of the types of relations Japanese firms tend to have with their banks. We find on average that firms having a so-called main bank relation tend to have a preference for multiple loan contacts (which seems to be counterintuitive, but has been found before in the literature). If the bank is a relatively important equity owner there is a relative decrease of the desire to have multiple relations. These effects tend to hold for the bubble (1981-1989) ad post-bubble (1990-1999) sub-samples. R\&Dintensive firms tended to want more bank relations.

The Japanese banking system has shown some drastic changes in the last few years. Bank concentration increased, so-called bad loans are transferred to special-purpose banks, and 
some bank managers have been replaced. Our paper shows that Japanese firms tend to have important links with multiple banks, which makes Japanese corporate behavior to be dependent on the developments in the banking sector. Especially for instance in R\&D intensive sectors the role of banks is big. As Ongena and Smith (2000a) argue, the stability of the banking sector interacts with the bank-firm networking systems. Banks being central to Japanese development therefore have indeed an apparent leading role in establishing conditions for a recovery of the Japanese economy. 


\section{References}

Aoki, Masahiko, Patrick, Hugh and Paul Sheard, 1994, The Japanese Main Bank System: An Introductory Overview, in: Aoki, Masahiko and Hugh Patrick (Eds.), The Japanese Main Bank System: Its Relevance for Developing and Transforming Economies, Oxford University Press , Oxford, 1-50.

Berglof, Erik and Enrico Perotti, 1994, The Governance Structure of the Japanese Financial Keiretsu, Journal of Financial Economics, 36, 259-284.

Bhattacharya, Sudipto and Gabriela Chiesa, 1995, Proprietary Information, Financial Intermediation and Research Incentives, Journal of Financial Intermediation, 4, 328-357.

Bolton, Patrick and David S. Scharfstein, 1996, Optimal Debt Structure and the Number of Creditors, Journal of Political Economy, 104, 1-25.

Boot, Arnoud W.A. and Anjan V. Thakor, 2000, Can Relationship Banking Survive Competition?, Journal of Finance, 55, 679-713.

Bris, Arturo and Ivo Welch, 2005, The Optimal Concentration of Creditors, Journal of Finance, 60, 2193-2212.

Broecker, Thorsten, 1990, Credit-Worthiness Tests and Interbank Competition, Econometrica, 58, 429-458.

Carletti, Elena, 2004, The Structure of Bank Relationships, Endogenous Monitoring and Loan Rates, Journal of Financial Intermediation, 13, 58-86.

Cole, Rebel A., 1998, The Importance of Relationships to the Availability of Credit, Journal of Banking and Finance, 22, 959-977.

D’Auria, Claudio, Antonella Foglia and and Paolo Marullo Reedtz, 1998, Bank interest rates and credit relations in Italy, Journal of Banking and Finance, 23, 1067-1093.

Degryse, Hans and Steven R.G. Ongena, 2001, Bank Relations and Firm Profitability, Financial Management, 30, 9-34.

Detragiache, Enrica, Paolo Garella and Luigi Guiso, 2000, Multiple versus Single Banking Relationships: Theory and Evidence, Journal of Finance, 55, 1133-1161.

Dewatripont, Mathias and Eric Maskin, 1995, Credit and Efficiency in Centralized and Decentralized Economies, Review of Economic Studies, 62, 541-555. 
Diamond, Douglas, 1984, Financial Intermediation and Delegated Monitoring, Review of Economic Studies, 51, 393-314.

Elsas, Ralf, 2001, Why do Banks View Themselves as a Relationship Lender?, Working Paper, Goethe-University, Frankfurt.

Farinha. Luisa A. and Joao A.C. Santos, 2004, Switching from Single to Multiple Bank Lending Relationships: Determinants and Implications, Journal of Financial Intermediation, 11, 124-151.

Flath, David, 1993, Shareholdings in The Keiretsu: Japan's Financial groups, Review of Economics and Statistics, 75, 249-257.

Foglia, Antonella, S. Laviola and Paolo Marullo Reedtz, 1998, Multiple Banking Relationships and the Financial Fragility of Corporate Borrowers, Journal of Banking and Finance, 22, 1441-1456.

Fukuda, Shin-ichi, 2001, The Role of Long-Term Loans for Economic Development: Empirical Evidence in Japan, Korea and Taiwan, Mimeo, University of Tokyo.

Harhoff, Dietmar and Thomas Korting, 1998, Lending Relationships in Germany Empirical Evidence from Survey Data, Journal of Banking and Finance, 22, 1317-1353.

Horiuchi, Akiyoshi, 1993, An Empirical Overview of the Japanese Main Bank Relationship in Relation to Firm Size, Rivista Internationale di Scienze Economiche e Commerciale, 40, 997-1018.

Horiuchi, Toshihiro, 1994, The Effect of Firm Status on Banking Relationships and Loan Syndication, in: Aoki, Masahiko and Hugh Patrick (Eds.), The Japanese Main Bank System, Oxford University Press, Oxford, 258-294.

Hoshi, Takeo and Anil Kashyap, 2001, Corporate Financing and Governance in Japan: The Road to the Future, MIT Press, Cambridge.

Hoshi, Takeo, Kashyap, Anil and David Scharfstein, 1990, The Role of Banks in Reducing the Costs of Financial Distress in Japan, Journal of Financial Economics, 27, 67-88.

Houston, Joel F. and Christopher James, 1995, Banking Relationships, Financial Constraints and Investment: Are Bank Dependent Borrowers More Financially Constrained? Mimeo, University of Florida.

Houston, Joel F. and Christopher James, 1996, Bank Information Monopolies and the Mix of Private and Public Debt Claims, Journal of Finance, 51, 1863-1889. 
Houston, Joel F. and Christopher James, 2001, Do Relationships Have Limits? Banking Relationships, Financial Constraints, and Investment, Journal of Business, 74, 347-374.

Ito, Takatoshi, 1992, The Japanese Economy, MIT Press, Cambridge.

Kang, Jun-Koo and Anil Shivdasani, 1995, Firm Performance, Corporate Governance and Top Executive Turnover in Japan, Journal of Financial Economics, 38, 29-58.

Kang, Jun-Koo and Anil Shivdasani, 1997, Corporate Restructuring during Performance Declines in Japan, Journal of Financial Economics, 46, 29-65.

Kaplan, Steven N. and Bernadette Minton, 1994, Appointments of Outsiders to Japanese Corporate Boards: Determinants and Implications for Managers, Journal of Financial Economics, 36, 225-258.

Miyajima, Hideaki, 1998, Sengo Nippon Kigyo niokeru Jyotai Izonteki Governance no Shinka to Henyo - Logit Model niyoru Keieisha Kotai Bunseki karano Approach - (The Evolution and Change of Contingent Governance Structure in the J-firm System - An Approach to Presidential Turnover and Firm Performance), Keizai Kenkyu, 49, 97-112. (in Japanese)

Morck, Randall and Masao Nakamura,1999, Banks and Corporate Control in Japan, Journal of Finance, 54, 319-339.

Ongena, Steven and David C. Smith, 2000a, What Determines the Number of Bank Relationships? Cross Country Evidence, Journal of Financial Intermediation, 9, 26-56.

Ongena, Steven and David C. Smith, 2000b, Bank Relationships: A Review, in: Harker, Patrick T. and Stavros A. Zenios (Eds.), Performance of Financial Institutions: Efficiency, Innovation, Regulation, Cambridge University Press, Cambridge, 221-258.

Ongena, Steven and David C. Smith, 2001, The Duration of Bank Relationships, Journal of Financial Economics, 61, 449-475.

Petersen, Mitchell A. and Raghuram G. Rajan, 1994, The Benefits of Lending Relationships: Evidence from Small Business Data, Journal of Finance, 49, 3-37.

Petersen, Mitchell A. and Raghuram G. Rajan, 1995, The Effect of Credit Market Competition on Lending Relationships, Quarterly Journal of Economics, 110, 406-443.

Prowse, Steven D., 1990, Institutional Investment Patterns and Corporate Financial Behavior in the U.S. and Japan, Journal of Financial Economics, 27, 43-66.

Rajan, Raghuram G., 1992, Insiders and Outsiders: The Choice Between Informed and Arm's Length Debt, Journal of Finance, 47, 1367-1400. 
Sekine, Toshitaka, Keiichiro Kobayashi and Yumi Saita, 2003, Forbearance lending: the case of Japanese firms, Bank of Japan Monetary and Economic Studies, 21, 69-92.

Sharpe, Steven A., 1990, Asymmetric Information, Bank Lending, and Implicit Contracts: A Stylized Model of Customer Relationships, Journal of Finance, 45, 10691087.

Sheard, Paul, 1989, the Main Bank System and Corporate Monitoring and Control in Japan, Journal of Economic Behavior and Organization, 11, 399-422.

Sheard, Paul, 1994a, Bank Executives on Japanese Corporate Boards, Bank of Japan Monetary and Economic Studies 12, 85-121.

Sheard, Paul, 1994b, Reciprocal Delegated Monitoring in the Japanese Main Bank System, Journal of the Japanese and International Economies, 8, 1-21.

Sheard, Paul, 1994c, Main Banks and the Governance of Financial Distress, in: Aoki, Masahiko and Hugh Patrick (Eds.), The Japanese Main Bank System: Its Relevance for Developing and Transforming Economies, Oxford University Press, Oxford, 188-230.

Shleifer, Andrei and Robert W. Vishny, 1997, A Survey of Corporate Governance, Journal of Finance, 52, 737-783.

Volpin, Paolo F., 2000, Ownership Structure, Banks, and Private Benefits of Control, IFA Working Paper, London Business School.

Von Rheinbaben, Joachim and Martin Ruckes, 1998, The Firm's Optimal Number of Bank Relationships and the Extent of Information Disclosure, Mimeo, University of Mannheim.

Von Thadden, Ernst-Ludwig, 1994, The Commitment of Finance, Duplicated Monitoring, and the Investment Horizon, Mimeo, Basle University.

Weinstein, David E. and Yishay Yafeh, 1998, On The Cost of a Bank-Centered Financial System: Evidence From the Changing Main Bank Relations in Japan, Journal of Finance, 53, 635-672.

Yosha, Oved, 1995, Information Disclosure Costs and the Choice of Financing Source, Journal of Financial Intermediation, 4, 3-20. 


\title{
CESifo Working Paper Series
}

\author{
(for full list see www.cesifo-group.de)
}

1529 Giorgio Fazio, Ronald MacDonald and Jacques Mélitz, Trade Costs, Trade Balances and Current Accounts: An Application of Gravity to Multilateral Trade, August 2005

1530 Thomas Christiaans, Thomas Eichner and Ruediger Pethig, A Micro-Level 'Consumer Approach’ to Species Population Dynamics, August 2005

1531 Samuel Hanson, M. Hashem Pesaran and Til Schuermann, Firm Heterogeneity and Credit Risk Diversification, August 2005

1532 Mark Mink and Jakob de Haan, Has the Stability and Growth Pact Impeded Political Budget Cycles in the European Union?, September 2005

1533 Roberta Colavecchio, Declan Curran and Michael Funke, Drifting Together or Falling Apart? The Empirics of Regional Economic Growth in Post-Unification Germany, September 2005

1534 Kai A. Konrad and Stergios Skaperdas, Succession Rules and Leadership Rents, September 2005

1535 Robert Dur and Amihai Glazer, The Desire for Impact, September 2005

1536 Wolfgang Buchholz and Wolfgang Peters, Justifying the Lindahl Solution as an Outcome of Fair Cooperation, September 2005

1537 Pieter A. Gautier, Coen N. Teulings and Aico van Vuuren, On-the-Job Search and Sorting, September 2005

1538 Leif Danziger, Output Effects of Inflation with Fixed Price- and Quantity-Adjustment Costs, September 2005

1539 Gerhard Glomm, Juergen Jung, Changmin Lee and Chung Tran, Public Pensions and Capital Accumulation: The Case of Brazil, September 2005

1540 Yvonne Adema, Lex Meijdam and Harrie A. A. Verbon, The International Spillover Effects of Pension Reform, September 2005

1541 Richard Disney, Household Saving Rates and the Design of Social Security Programmes: Evidence from a Country Panel, September 2005

1542 David Dorn and Alfonso Sousa-Poza, Early Retirement: Free Choice or Forced Decision?, September 2005

1543 Clara Graziano and Annalisa Luporini, Ownership Concentration, Monitoring and Optimal Board Structure, September 2005 
1544 Panu Poutvaara, Social Security Incentives, Human Capital Investment and Mobility of Labor, September 2005

1545 Kjell Erik Lommerud, Frode Meland and Odd Rune Straume, Can Deunionization Lead to International Outsourcing?, September 2005

1546 Robert Inklaar, Richard Jong-A-Pin and Jakob de Haan, Trade and Business Cycle Synchronization in OECD Countries: A Re-examination, September 2005

1547 Randall K. Filer and Marjorie Honig, Endogenous Pensions and Retirement Behavior, September 2005

1548 M. Hashem Pesaran, Til Schuermann and Bjoern-Jakob Treutler, Global Business Cycles and Credit Risk, September 2005

1549 Ruediger Pethig, Nonlinear Production, Abatement, Pollution and Materials Balance Reconsidered, September 2005

1550 Antonis Adam and Thomas Moutos, Turkish Delight for Some, Cold Turkey for Others?: The Effects of the EU-Turkey Customs Union, September 2005

1551 Peter Birch Sørensen, Dual Income Taxation: Why and how?, September 2005

1552 Kurt R. Brekke, Robert Nuscheler and Odd Rune Straume, Gatekeeping in Health Care, September 2005

1553 Maarten Bosker, Steven Brakman, Harry Garretsen and Marc Schramm, Looking for Multiple Equilibria when Geography Matters: German City Growth and the WWII Shock, September 2005

1554 Paul W. J. de Bijl, Structural Separation and Access in Telecommunications Markets, September 2005

1555 Ueli Grob and Stefan C. Wolter, Demographic Change and Public Education Spending: A Conflict between Young and Old?, October 2005

1556 Alberto Alesina and Guido Tabellini, Why is Fiscal Policy often Procyclical?, October 2005

1557 Piotr Wdowinski, Financial Markets and Economic Growth in Poland: Simulations with an Econometric Model, October 2005

1558 Peter Egger, Mario Larch, Michael Pfaffermayr and Janette Walde, Small Sample Properties of Maximum Likelihood Versus Generalized Method of Moments Based Tests for Spatially Autocorrelated Errors, October 2005

1559 Marie-Laure Breuillé and Robert J. Gary-Bobo, Sharing Budgetary Austerity under Free Mobility and Asymmetric Information: An Optimal Regulation Approach to Fiscal Federalism, October 2005 
1560 Robert Dur and Amihai Glazer, Subsidizing Enjoyable Education, October 2005

1561 Carlo Altavilla and Paul De Grauwe, Non-Linearities in the Relation between the Exchange Rate and its Fundamentals, October 2005

1562 Josef Falkinger and Volker Grossmann, Distribution of Natural Resources, Entrepreneurship, and Economic Development: Growth Dynamics with Two Elites, October 2005

$1563 \mathrm{Yu}-\mathrm{Fu}$ Chen and Michael Funke, Product Market Competition, Investment and Employment-Abundant versus Job-Poor Growth: A Real Options Perspective, October 2005

1564 Kai A. Konrad and Dan Kovenock, Equilibrium and Efficiency in the Tug-of-War, October 2005

1565 Joerg Breitung and M. Hashem Pesaran, Unit Roots and Cointegration in Panels, October 2005

1566 Steven Brakman, Harry Garretsen and Marc Schramm, Putting New Economic Geography to the Test: Free-ness of Trade and Agglomeration in the EU Regions, October 2005

1567 Robert Haveman, Karen Holden, Barbara Wolfe and Andrei Romanov, Assessing the Maintenance of Savings Sufficiency Over the First Decade of Retirement, October 2005

1568 Hans Fehr and Christian Habermann, Risk Sharing and Efficiency Implications of Progressive Pension Arrangements, October 2005

1569 Jovan Žamac, Pension Design when Fertility Fluctuates: The Role of Capital Mobility and Education Financing, October 2005

1570 Piotr Wdowinski and Aneta Zglinska-Pietrzak, The Warsaw Stock Exchange Index WIG: Modelling and Forecasting, October 2005

1571 J. Ignacio Conde-Ruiz, Vincenzo Galasso and Paola Profeta, Early Retirement and Social Security: A Long Term Perspective, October 2005

1572 Johannes Binswanger, Risk Management of Pension Systems from the Perspective of Loss Aversion, October 2005

1573 Geir B. Asheim, Wolfgang Buchholz, John M. Hartwick, Tapan Mitra and Cees Withagen, Constant Savings Rates and Quasi-Arithmetic Population Growth under Exhaustible Resource Constraints, October 2005

1574 Christian Hagist, Norbert Klusen, Andreas Plate and Bernd Raffelhueschen, Social Health Insurance - the Major Driver of Unsustainable Fiscal Policy?, October 2005

1575 Roland Hodler and Kurt Schmidheiny, How Fiscal Decentralization Flattens Progressive Taxes, October 2005 
1576 George W. Evans, Seppo Honkapohja and Noah Williams, Generalized Stochastic Gradient Learning, October 2005

1577 Torben M. Andersen, Social Security and Longevity, October 2005

1578 Kai A. Konrad and Stergios Skaperdas, The Market for Protection and the Origin of the State, October 2005

1579 Jan K. Brueckner and Stuart S. Rosenthal, Gentrification and Neighborhood Housing Cycles: Will America’s Future Downtowns be Rich?, October 2005

1580 Elke J. Jahn and Wolfgang Ochel, Contracting Out Temporary Help Services in Germany, November 2005

1581 Astri Muren and Sten Nyberg, Young Liberals and Old Conservatives - Inequality, Mobility and Redistribution, November 2005

1582 Volker Nitsch, State Visits and International Trade, November 2005

1583 Alessandra Casella, Thomas Palfrey and Raymond Riezman, Minorities and Storable Votes, November 2005

1584 Sascha O. Becker, Introducing Time-to-Educate in a Job Search Model, November 2005

1585 Christos Kotsogiannis and Robert Schwager, On the Incentives to Experiment in Federations, November 2005

1586 Søren Bo Nielsen, Pascalis Raimondos-Møller and Guttorm Schjelderup, Centralized vs. De-centralized Multinationals and Taxes, November 2005

1587 Jan-Egbert Sturm and Barry Williams, What Determines Differences in Foreign Bank Efficiency? Australian Evidence, November 2005

1588 Steven Brakman and Charles van Marrewijk, Transfers, Non-Traded Goods, and Unemployment: An Analysis of the Keynes - Ohlin Debate, November 2005

1589 Kazuo Ogawa, Elmer Sterken and Ichiro Tokutsu, Bank Control and the Number of Bank Relations of Japanese Firms, November 2005 